\title{
Sponge assemblages and predicted archetypes in the eastern Canadian Arctic
}

\author{
Francisco Javier Murillo ${ }^{1, *}$, Ellen Kenchington ${ }^{1}$, Gabrielle Tompkins ${ }^{1,2}$, \\ Lindsay Beazley ${ }^{1}$, Emily Baker ${ }^{1}$, Anders Knudby ${ }^{3}$, Wojciech Walkusz ${ }^{4}$
}

\author{
${ }^{1}$ Department of Fisheries and Oceans, Bedford Institute of Oceanography, Dartmouth, Nova Scotia B2Y 4A2, Canada \\ ${ }^{2}$ Biology Department, Dalhousie University, Halifax, Nova Scotia B3H 4R2, Canada \\ ${ }^{3}$ Department of Geography, Environment and Geomatics, University of Ottawa, Ottawa, Ontario K1N 6N5, Canada \\ ${ }^{4}$ Department of Fisheries and Oceans, Freshwater Institute, Central and Arctic Region, Winnipeg, Manitoba R3T 2N6, Canada
}

\begin{abstract}
Little information exists on the environmental requirements of sponges from the Canadian Arctic, increasing the necessity to establish baseline distribution data on sponge assemblages to predict their susceptibility to climate change. Here we describe the sponge taxa of Hudson Strait, Ungava Bay, Western Davis Strait and Western Baffin Bay collected by Canadian research vessel trawl surveys. A total of 2026 sponge specimens were examined, and 93 different taxa were identified with $79 \%$ identified to species, of which 2 are new to science, 1 recorded for the first time in the North Atlantic, 16 are new records for the northwest Atlantic, and 10 are new records for the Baffin Bay, Davis Strait and Hudson Strait sponge fauna. Taxonomic distinctness was higher north of Cape Dyer and south of Davis Strait, whereas the number of species reached a maximum in Davis Strait, which represents the southern distribution limit of the arctic sponge fauna along the slope in this region. Five sponge species assemblages were identified, some of which have been observed elsewhere, suggesting that they may be common to the North Atlantic and at the generic level to the global oceans. Two of the Baffin Bay-Davis Strait assemblages were characterized by large structure-forming astrophorids: one, with arctic species, found at midwater depths in Baffin Bay and the other, characterized by boreal species, was found deeper, south of Davis Strait. Another assemblage characterized by glass and carnivorous sponges was found along the continental slope of western Baffin Bay. Candidate target indicator species are provided for future sponge community monitoring.
\end{abstract}

KEY WORDS: Sponge grounds - Biodiversity $\cdot$ Community modelling $\cdot$ Community structure Significant Benthic Areas · Davis Strait · Baffin Bay

\section{INTRODUCTION}

Sponges are a primitive group of sessile, largely marine, multicellular animals that actively filter feed on particle-laden water by pumping ambient water through their aquiferous canal system, or by engulfing food particles in the case of carnivorous sponges. Dense aggregations of sponges, or sponge grounds, create structurally complex biogenic habitats that locally increase biodiversity (e.g. Bett \& Rice 1992, Klitgaard 1995, Beazley et al. 2013, 2015), and pro-

${ }^{*}$ Corresponding author: javier.murillo-perez@dfo-mpo.gc.ca vide food, shelter and/or nursery areas for other species (e.g. Herrnkind et al. 1997, Freese \& Wing 2003, Amsler et al. 2009, Wareham Hayes et al. 2017). Further, estimates of bulk water processing by sponges (e.g. Leys et al. 2011, Kutti et al. 2013, Lesser \& Slattery 2013) highlight their important role in benthic-pelagic coupling, largely through nutrient cycling (e.g. Pile \& Young 2006, Bell 2008, Maldonado et al. 2012, 2017, Kahn et al. 2015).

In the northwest Atlantic, along the continental slopes, sponges can make up the majority of the ben-

(c) Fisheries and Oceans Canada, G. Tompkins, A. Knudby 2018. Open Access under Creative Commons by Attribution Licence. Use, distribution and reproduction are unrestricted. Authors and original publication must be credited. 
thic biomass (Fuller 2011, Murillo et al. 2012, Knudby et al. 2013), and in the eastern Canadian Arctic, sponges and sponge grounds occur in both Davis Strait and Baffin Bay (Knudby et al. 2013, Kenchington et al. 2016a,b), which have been identified as Significant Benthic Areas (Kenchington et al. 2016a,b). Sponge communities from the northeast Atlantic (Klitgaard \& Tendal 2004) and the northwest Atlantic (Fuller 2011, Murillo et al. 2012, 2016b) have been described, and include arctic and boreal astrophorid grounds with similar species compositions. However, there has not been a recent systematic review of the sponge species of the eastern Canadian Arctic, and the major sponge communities present in these areas remain unknown.

In the late $19^{\text {th }}$ century, Fristedt (1887) documented 12 species of sponge from the Baffin Bay-Davis Strait area and the west Greenland shelf. Following this work, Lambe (1900) recorded 21 species from northeastern Canada, with 15 from the Davis Strait, and Lundbeck (1902) documented 15 sponge species from the west Greenland shelf. Brøndsted (1933) reviewed previous works and added 36 records to the sponge fauna in waters west of Greenland, with 3 new to science and 15 recorded for the first time from this area. Together, these early descriptions listed 112 sponge species from west Greenland waters (Brøndsted 1933) and form the basis of the known sponge fauna of the Baffin Bay-Davis Strait region. Recent taxonomic reviews on the genus Geodia (Cárdenas et al. 2013b), and the families Tetillidae (Cárdenas et al. 2013a), Cladorhizidae (Hestetun et al. 2017) and Polymastiidae (Plotkin et al. 2017) included new records to the area.

Understanding the parameters that potentially control the distribution of sponge assemblages in the eastern Canadian Arctic will help to predict their susceptibility to the projected rapid and imminent environmental change in this region (e.g. Zhang et al. 2008, Boé et al. 2009, Ding et al. 2014). However, with the exception of Knudby et al. (2013), Beazley et al. (2016) and Howell et al. (2016), little information exists on the environmental requirements of sponges from this area, increasing the necessity to establish baseline distribution data on sponge assemblages.

Here, we present results on the diversity and composition of sponges collected from 5 annual multispecies trawl surveys carried out within assessment areas for Greenland halibut and northern shrimp in the eastern Canadian Arctic, specifically in Hudson Strait, Ungava Bay, Western Davis Strait and Western Baffin Bay. This study provides the first detailed description of sponge diversity and assemblages in the eastern Canadian Arctic. We discuss the oceano- graphic settings under which the eastern Canadian Arctic sponge species and assemblages occur and use predictive models to extrapolate the species archetype-environment relationships across to Greenland. Finally, we compare our sponge assemblages with boreal and arctic sponge communities described in independent studies elsewhere in the North Atlantic, and identify candidate target species for future sponge community monitoring.

\section{MATERIALS AND METHODS}

\section{Study area and environmental setting}

The study area to which our analyses were applied was a combination of 2 Fisheries and Oceans Canada (DFO) Biogeographic Regions in the eastern Canadian Arctic: the Eastern Arctic Biogeographic Region and the Hudson Strait/Ungava Bay portion of the Hudson Bay Complex Biogeographic Region. These biogeographic regions were formed based on knowledge of oceanographic provinces and species distributions (DFO 2009) and were created to facilitate marine protected area (MPA) network design in the regions managed by DFO. For our study, we extended the boundary eastward beyond the 200 nautical mile Canadian Exclusive Economic Zone to the coast of Greenland to ensure the large water bodies Davis Strait and Baffin Bay were included in their entirety in our predictive models (Fig. 1).

The study area included 3 large bodies of water: Baffin Bay, Davis Strait and Hudson Strait. Baffin Bay (Fig. 1) connects to the Arctic Ocean directly through 3 small straits: Nares Strait to the north and Jones Sound and Lancaster Sound to the west. Baffin Bay is considered a marginal sea or small ocean basin created through sea floor spreading (Keen et al. 1974) and is seismically active in the northwest (Reid \& Falconer 1982). Baffin Basin, the deepest part of Baffin Bay, is greater than $2000 \mathrm{~m}$ in depth. The shelves extending from both Canada and Greenland include several large shoals or banks typically ranging between 20 and $100 \mathrm{~m}$ in depth and traversed by deep troughs, and the coastline in many areas is marked by fjords. In northern Baffin Bay, the North Water Polynya is one of the largest seasonal open-water areas of the Arctic (Melling et al. 2001, Tang et al. 2004) and historically is one of the most biologically productive waters in the Arctic. On the Baffin Island Shelf, ice-free areas persist for about $60 \mathrm{~d}$, and about $200 \mathrm{~d}$ on the west Greenland shelf, and the maximum ice draft is $20 \mathrm{~m}$ (Wu et al. 2013). 


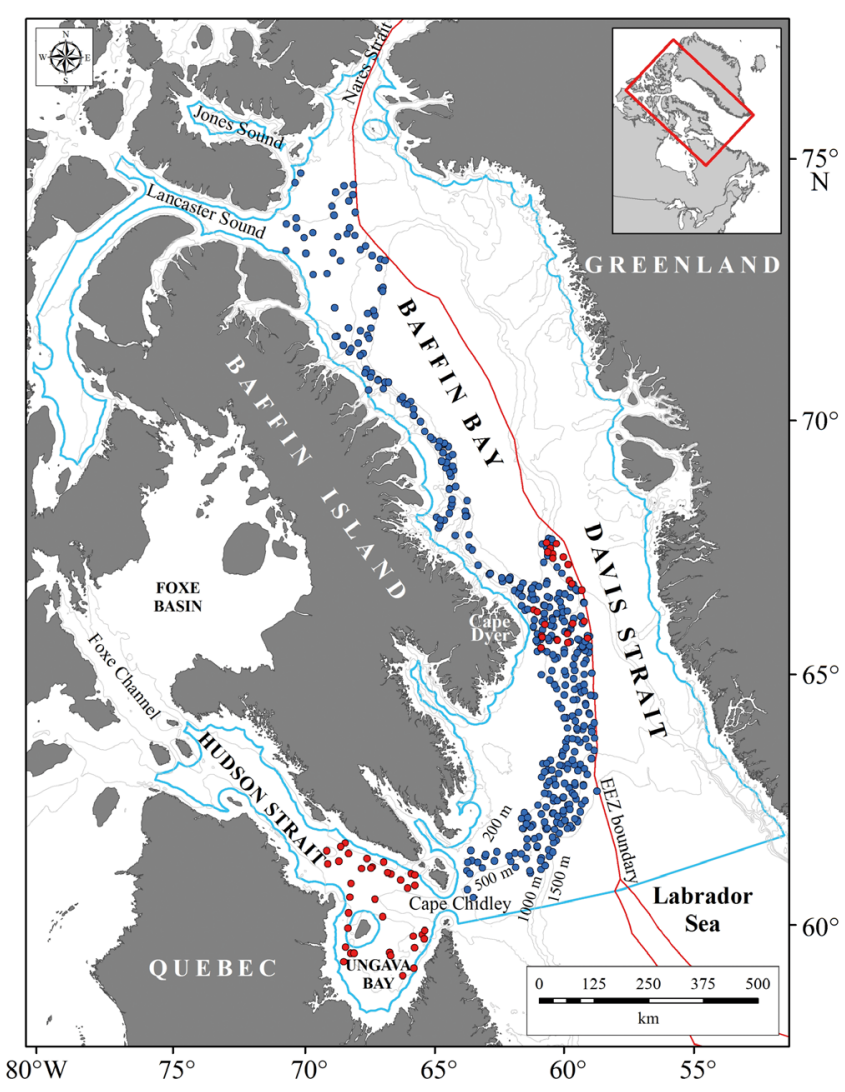

Fig. 1. Study area in the eastern Arctic. The exclusive economic zone (EEZ) boundaries of Canada and Greenland are indicated by a red line. The positions of the 456 depth-stratified random trawl locations used to sample the sponges are indicated by the blue (Alfredo gear) and red (Cosmos gear) circles. The light blue polygon represents the extent of the area used in the modelling analysis

Davis Strait (Fig. 1) is a $350 \mathrm{~km}$ wide strait that joins 2 oceanic basins, Baffin Bay to the north and the Labrador Sea to the south, and separates southwestern Greenland and southeastern Baffin Island, the latter constituting the largest island in the Canadian Arctic Archipelago. It is considered the largest strait in the world and is renowned for its exceptionally large tidal range, from 9 to $18 \mathrm{~m}$, and a complex hydrography (Wu et al. 2013). At its narrowest point, a ridge or sill up to $600 \mathrm{~m}$ depth extends between Greenland (at Holsteinborg, Sisimiut) and Canada (at Cape Dyer, Baffin Island). The slopes at the Labrador Sea flank of the sill drop to 2500 m or more, and Kenchington et al. (2016b) found that the highest biomass of sponges occurred in this area, with up to $2 \mathrm{t}$ of sponge biomass removed from a single $1.5 \mathrm{~km}$ research trawl with Campelen gear.

Hudson Strait (Fig. 1) in the southwest of the study area is a long $(720 \mathrm{~km})$, narrow $(64-240 \mathrm{~km})$ strait that separates Baffin Island and northern Quebec,
Canada. It averages $100 \mathrm{~m}$ depth through most of its extent but drops to $1000 \mathrm{~m}$ at its maximum depth in the opening of the channel to the Davis Strait, south of Resolution Island (Drinkwater 1988). Hudson Strait is characterized by high diurnal tides (3-6 m) and strong tidal currents (reaching $2 \mathrm{~m} \mathrm{~s}^{-1}$ ) (Drinkwater 1988), and receives water from Hudson Bay and Foxe Basin via Foxe Channel and carries it through to the Labrador Sea. Ungava Bay, approximately $50000 \mathrm{~km}^{2}$ in area, is a shallow (<150 m) embayment (Fig. 1), with a number of islets, the largest being Akpatok Island. It is known for its extreme tidal range $(17 \mathrm{~m})$. Hudson Strait/Ungava Bay form part of the Hudson Bay Complex Biogeographic Region (DFO 2009) and are expected to have different faunal compositions and oceanographic characteristics from the Eastern Arctic Biogeographic Region.

\section{Sponge data}

Sponges were collected in Baffin Bay, Davis Strait and Hudson Strait during 5 annual multispecies trawl surveys (2010-2014) conducted by DFO on the Greenland Institute of Natural Resources (GINR) RV 'Paamiut'. These surveys were conducted to provide fisheries-independent data on the status of Greenland halibut for stock assessments in the Northwest Atlantic Fisheries Organization (NAFO) Subdivisions 0A and 0B (Baffin Bay/Davis Strait) with a depth coverage of 100-1500 m. The survey was performed with Alfredo trawl gear towed at 3 knots for 30 min at each station (Fig. 1). Additionally, in 2010 and 2012, a small area of the NAFO 0A Division, referred to as the Shrimp Fishing Area 1 (SFA1), was surveyed to assess the stock of northern shrimp. In 2011 and 2013, samples were collected during surveys of northern and striped shrimp in SFA3 in the Central and Arctic DFO Regions (Hudson Strait/Ungava Bay) with a depth coverage of 100-1000 m. These shrimp surveys were performed with a Cosmos 2000 shrimp trawl towed at 2.6 knots for $15 \mathrm{~min}$ at each station (Fig. 1). A buffered random sampling approach designed by Kingsley et al. (2004) was employed on all surveys, and the areas were divided into the depth strata, i.e. 100-200, 200-300, 300-400, 400-500, 500-750 and $>750 \mathrm{~m}$.

Sponges collected during the survey were tentatively identified using previously established at-sea identification guides, then frozen and later examined in the laboratory for further taxonomic identification. Species were identified via spicule and morphological analysis (e.g. Koltun 1959, 1966, Cárdenas et al. 
2013b, Hestetun et al. 2017). Detailed descriptions and taxonomic discussion of some of the species included in this paper have been published elsewhere (e.g. Tompkins et al. 2017, Baker et al. 2018) and in broader taxonomic reviews (e.g. Cárdenas et al. 2013b, Hestetun et al. 2017). Most sponges were identified to species level. However, in some cases, the size range of the spicules or other diagnostic characters did not exactly match the species descriptions. These are qualified as cf. or aff. (Lucas 1986), using aff. as a more uncertain identification than cf. A few taxa included in our study likely contained multiple species. An exploratory cluster analysis of the species identified was run with and without these taxa, and no appreciable differences were detected in group configuration; consequently, they were retained for subsequent analyses.

For statistical analyses, only trawl sets with complete data were considered, resulting in a total of 472 trawl sets. Sets where the presence of sponges was recorded, but no sample was provided and/or the sponges were not identifiable from at-sea photos, as well as sets where only a small subset of sponges could be identified were not used in the analysis. This resulted in the loss of 4 taxa from the analyses: Geodia parva/phlegraei, Iotrochotidae sp., Lissodendoryx (Ectyodoryx) aff. diversichela and Myxilla (Myxilla) cf. incrustans.

\section{Sponge diversity indices}

The total number of species $(S)$, average taxonomic distinctness $\left(\Delta^{+}\right)$and variation in taxonomic distinctness $\left(\Lambda^{+}\right)$(Warwick \& Clarke 1995, Clarke \& Warwick 2001) were calculated using the 'vegan' package (Oksanen et al. 2017) from the statistical computing software R 3.2.5 (R Core Team 2016). Such indices are only meaningful if applied to 1 taxocene using the same survey protocols over space and time (Kenchington \& Kenchington 2013). In our study, the taxocene is defined as non-encrusting sponges captured with bottom trawl gear in the Canadian portion of Baffin Bay, Davis Strait and Hudson Strait (including Ungava Bay), i.e. the survey spatial extent (Fig. 1). The 2 different gear types, only overlapping in a small area north of Davis Strait, have known differences in catchability of sponges (Kenchington et al. 2010). Consequently, we discounted biomass data in this study and used only presence/absence data in order to reduce this effect. The survey protocols were the same across years. Confirmation of no difference in the indices between gear types was achieved through Kolmogorov-Smirnov tests computed for the trawl sets located in the area where both gears overlapped (Fig. 1). Species accumulation plots with 999 randomized permutations were calculated using the 'vegan' (Oksanen et al. 2017) package in R. Scatterplots of each diversity index versus depth $(\mathrm{m})$ and latitude were created. A LOESS smoother was overlaid to each plot to identify trends.

\section{Community analyses}

A cluster analysis of the sampling stations based on sponge species composition was created using the index of similarity of Sørensen and the isometric feature mapping and partitioning around medioids (Isopam) algorithm (Schmidtlein et al. 2010, Murillo et al. 2016b). An ordered synoptic table summarizing the frequency of species in the groups obtained, along with their significance (assessed at $\alpha=0.01$ ) based on the phi coefficient $(\Phi)$ of their association to clusters (Tichý \& Chytrý 2006) was produced. The phi value measures the degree of association of 1 species to 1 cluster (fidelity of the species to the cluster) and ranges from 1 to -1 with an associated $p$ value. A threshold value of $\Phi=0.23$, based on the numbers of clusters, stations and species (Schmidtlein 2015), was used to distinguish species with high $(\geq 0.23)$ and low $(<0.23)$ fidelity to the cluster group. The analyses were done using the 'isopam' (Schmidtlein 2015) package in R.

\section{Species archetype modelling}

A model-based clustering method developed by Dunstan et al. (2011) and referred to as species archetype modelling (SAM) was used to predict the probability of occurrence distribution for sponge assemblages in the Eastern Arctic. This modelling method uses finite mixture models (McLachlan \& Peel 2000) to cluster species based on their environmental responses. Species that have a similar response to environmental conditions are grouped together and represented by a single logistic generalized linear model (GLM). These groups are referred to as species archetypes. The archetype GLMs are derived from a single finite mixture model and represent 1 or many species with similar ecological tolerances. This analysis allows the estimation of both group composition and the shared response to occur simultaneously, so the fitted models provide the probability of a species belonging to a particular species archetype 
and the GLM for each species archetype that describes the response of that group to the environment (Leaper et al. 2014). This method also provides accurate predictions for rare species by borrowing strength from the most prevalent species classified into the same archetype (Hui et al. 2013). The SAMs were built using the 'SpeciesMix' (Dunstan et al. 2015) package in $R$.

Model selection followed the approach of Leaper et al. (2014). A full model including all covariate and quadratic terms was used to select the number of species archetypes. The covariates used were previously standardized to a mean of 0 and variance of 1 (Dunstan et al. 2013, Hui et al. 2015, Galanidi et al. 2016). The most parsimonious model was determined by comparing models with different species archetypes $(G)$ using the Bayesian information criterion (BIC) (Schwarz 1978). The plot of $\triangle \mathrm{BIC}(G)$, which is defined as $\operatorname{BIC}(G)-\operatorname{BIC}(G+1)$, highlights the values of $G$ where BIC increases. The first increase in $\triangle \mathrm{BIC}(G)$, which is represented with the first negative value, indicates the 'best' value of $G$ and was used to select the number of archetypes. In order to prevent fitting too many species archetypes, the minimum probability $(\pi)$ estimated of the archetype groups should be higher than the a priori probability of there being 1 species in a group $(1 / S)$, where $S$ is the number of species (Dunstan et al. 2011). The estimated model parameters were obtained using the expectation-maximization algorithm where multiple starting values (20) were used to help convergence to the global maximum (Dunstan et al. 2011, 2013).

Variable selection is still a challenge in mixture modelling (e.g. McLachlan \& Peel 2000, Grimm et al. 2017), and new methods are being developed (e.g. Hui et al. 2015, Grimm et al. 2017). Often researchers remove covariates with high standard errors (Woolley et al. 2013, Galanidi et al. 2016) or fit a series of models comparing the fit statistics to determine the optimal model (Leaper et al. 2014). In the present study, once the number of archetypes was selected, models with different covariates were evaluated in a stepwise approach to minimize the BIC. Covariates with high relative standard error (RSE, where RSE is the standard error [SE] of the absolute value of the parameter multiplied by 100 and divided by the estimated coefficient), were removed from the model, as a covariate will be important in the model if it has a small SE relative to the size of the estimated value. The model with the lowest BIC was used to predict the presence probability and the SE of each sponge archetype in the sampling locations and in each pixel of the study area. The probability of belonging to an archetype is calculated as the ratio of the likelihood of a particular archetype to the sum of the likelihoods of all archetypes for that species. Marginal effect of each final model predictor was visualized with partial plots created by taking predicted probability calculated by varying a single predictor while keeping all others at their respective mean values. The maximum archetype probability was also computed for each of the sampling locations in order to characterize each location based on its archetype dominance.

To independently corroborate the results of the GLMs and identified archetypes, the SAM results were compared with the distribution of sponge community types produced from Isopam in order to evaluate if the species archetypes, which respond only to the environmental conditions, are similar to the assemblages of sponges identified using only the cooccurrence of species. In addition, model performance was evaluated for individual species. Expected probability of occurrence was calculated for each species following Galanidi et al. (2016), and the Kendall rank correlation coefficient between observed and expected values and the area under the receiver operating characteristic curve (AUC) were computed for each species.

\section{Environmental variables}

Sixty-six environmental variables, derived from different sources and with varying native spatial resolutions (from 0.5 to $111 \mathrm{~km}$ ), were used to develop the SAMs. These variables were chosen based on their availability and assumed relevance to the distribution of sponge fauna. All variables except depth and slope were derived from long-term modelled oceanographic or remotely sensed data and were spatially interpolated across the study area using ordinary kriging in ArcMap 10.2.2 software (ESRI 2011). Specific details on the methods used for the spatial interpolation of these variables as well as quantitative assessment of the quality of the interpolations are documented in Beazley et al. (2018). All predictor layers were displayed in raster format with geographic coordinates using the WGS 1984 datum and a $\sim 0.013^{\circ}$ cell size (approximately equal to $1 \mathrm{~km}$ horizontal resolution at $75^{\circ} \mathrm{N}$ ). Due to the $20 \mathrm{~km}$ land buffer (Fig. 1) applied to the environmental variables (Beazley et al. 2018), 16 trawl sets close to land were excluded from the analyses and resulted in 456 trawl sets for the analysis. Variables that include the syntax 'avg' followed by min, max or range were calculated by taking the minimum, maximum or range values at 
each location across all months within a year or season, and averaging across years (Beazley et al. 2018).

Highly correlated environmental variables were identified and eliminated prior to use in order to produce interpretable models and reduce the effect of collinearity (Graham 2003). This was done following the variable elimination procedure outlined by Knudby et al. (2013). Spearman's rank correlation coefficients $(\rho)$ between predictor variables were calculated from all raster cells in the study area (Fig. S1 in the Supplement at www.int-res.com/articles/suppl/ m597p115_supp.pdf), and the 2 predictors with the highest correlation were then considered; one of these was then eliminated. This process was repeated until there were no variables remaining that were correlated higher than 0.5 . The 12 predictor variables remaining are shown in Table 1. Inclusion of spatial location in the model can help to delineate patterns (Leaper et al. 2014, Foster et al. 2015). However, latitude and longitude were correlated $(|\rho|>$ 0.5 ) with bottom temperature, and they were not included in the model as the latter is thought to be more biologically and ecologically relevant (Knudby et al. 2013).

\section{RESULTS}

In total, we examined 2026 sponge specimens collected from 456 trawl sets (Fig. 1), and 93 different taxa were identified (Table 2). Of these, $79 \%$ of specimens were confidently identified to 86 putative species, of which 2 are new to science, 1 is recorded for the first time in the North Atlantic, 16 are new records for the northwest Atlantic (for a full descrip- tion of 7 of them, see Tompkins et al. 2017 and Baker et al. 2018), and 10 are new records for the Baffin Bay, Davis Strait and Hudson Strait sponge fauna (Table 2). Another 5 species tentatively identified and pending confirmation (qualified as 'aff.') could include additional new records for the area or new species to science. From all of the taxa identified (93), more than half (65) can be considered rarities in the area (present in fewer than 21 trawl sets, i.e. $\leq 5 \%$ occurrence).

Of the 4 sponge classes, 3 (Demospongiae, Calcarea and Hexactinellida) were represented amongst the samples, with the vast majority of taxa (>90\%) being demosponges. Sponges from the Demospongiae were the most diverse and were represented by 10 orders and 29 families. The glass sponge Asconema foliata and the demosponge Mycale (Mycale) lingua were the most frequently occurring species, found in 130 and 98 trawl sets ( 29 and $21 \%$ ), respectively.

\section{Sponge diversity indices}

The number of species per station ranged from 1 to 17 with a mean $( \pm \mathrm{SD})$ of $4( \pm 3)$. The most diverse stations (i.e. those with 17 sponge taxa) occurred east of Cape Dyer, Baffin Island in the Davis Strait (Figs. 2A \& 3B) between 450 and $900 \mathrm{~m}$ depth (Fig. 3A). Taxonomic distinctness was higher north of Cape Dyer and south of Davis Strait (Fig. 2B), although no clear pattern was observed in relation to depth and latitude (Fig. 3C,D). Variation in taxonomic distinctness presented a similar pattern to species richness (Fig. 3E,F).
Table 1. Environmental variables remaining after variable elimination. Avg max (min): average maximum (minimum); na: not applicable. Avg max and avg min were calculated by taking the maximum and minimum values at each location across all months within a year or season, and averaging across years (Beazley et al. 2018)

\begin{tabular}{|lccc|}
\hline Variable & Metric & Unit & $\begin{array}{c}\text { Native } \\
\text { resolution }\end{array}$ \\
\hline Depth & na & $\mathrm{m}$ & 30 arc-sec \\
Slope & na & degrees & 30 arc-sec \\
Bottom temperature & Avg max & ${ }^{\circ} \mathrm{C}$ & $14^{\circ}$ \\
Bottom current speed & Avg max & $\mathrm{m} \mathrm{s}^{-1}$ & $14^{\circ}$ \\
Surface current speed & Avg max & $\mathrm{m} \mathrm{s}^{-1}$ & $14^{\circ}$ \\
Spring mixed layer depth & Avg max & $\mathrm{m}^{\circ}$ & $14^{\circ}$ \\
Spring ice cover & Range & $\%^{\circ}$ & $1^{\circ}$ \\
Spring chlorophyll a & Avg min, avg max & $\mathrm{mg} \mathrm{m}^{-3}$ & $9 \mathrm{~km}$ \\
Summer chlorophyll a & Avg max & $\mathrm{mg} \mathrm{m}^{-3}$ & $9 \mathrm{~km}$ \\
Summer primary production & Avg max, range & $\mathrm{mg} \mathrm{C} \mathrm{m}^{-2} \mathrm{~d}^{-1}$ & $9 \mathrm{~km}$ \\
\hline
\end{tabular}

\section{Community analyses}

Seventy of the 93 species recorded were present at more than 1 sampling station. Isopam identified 3 groups at the first classification level (identified as I, II, III in Table S1 in the Supplement). Groups II and III were further partitioned to subgroups a and $\mathrm{b}$, producing 5 significant species groups formed by 23 species with high fidelity to their groups. Group I was comprised of 2 species that were not significantly associated with any other cluster, Chondrocladia (Chondrocladia) gran- 
Table 2. Species archetypes and Isopam clusters associated with the highest fidelity of the species (represented by $\Phi$ ). Species are ordered by species archetype and number of occurrences (n). Species only present at 1 station were not included in the Isopam analysis and are indicated by the dash (-) symbol. A $\Phi$ threshold value of 0.23 was used to distinguish species with high $(\geq 0.23)$ and low $(<0.23)$ fidelity to the cluster group. na: not applicable

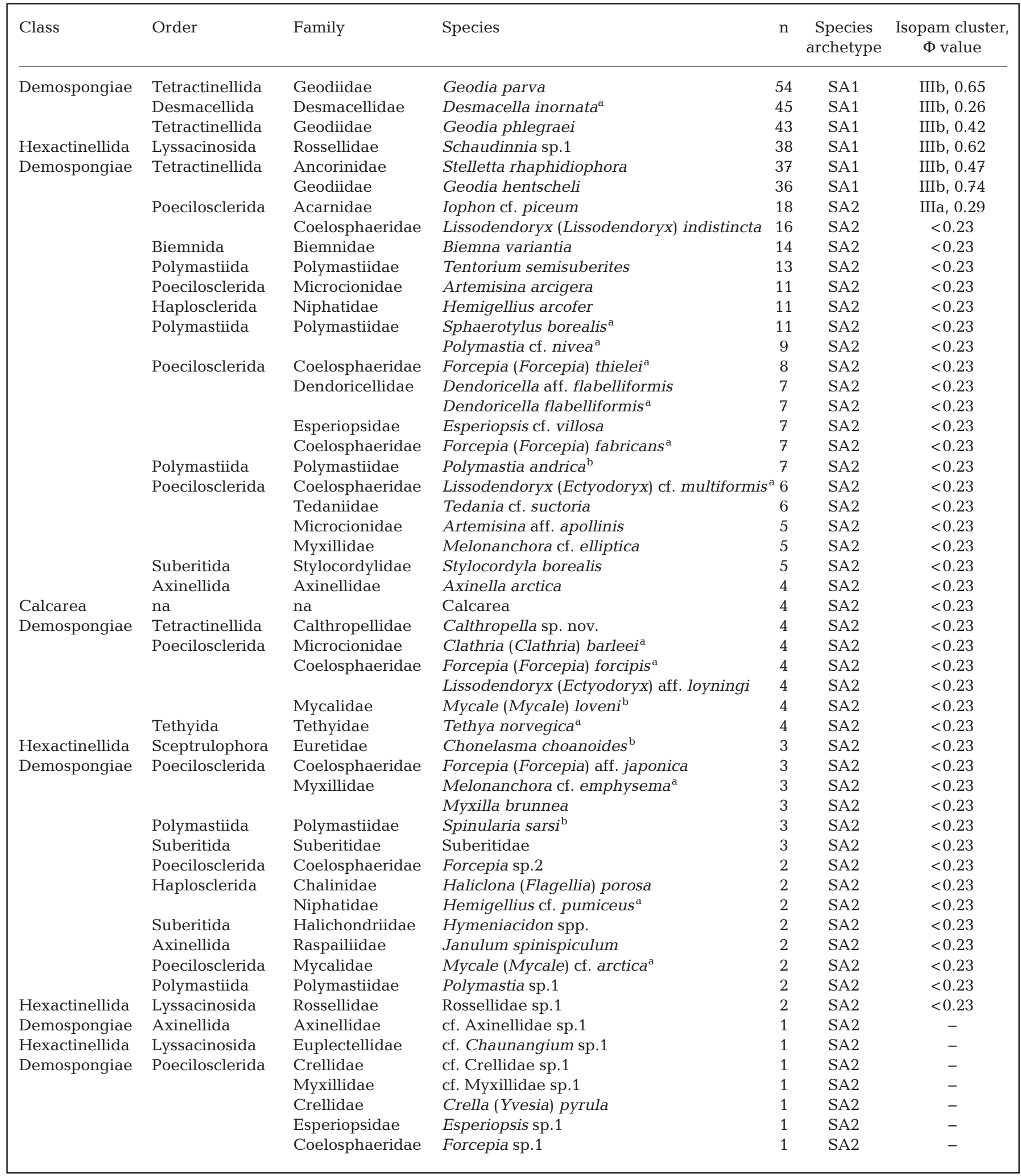


Table 2 (continued)

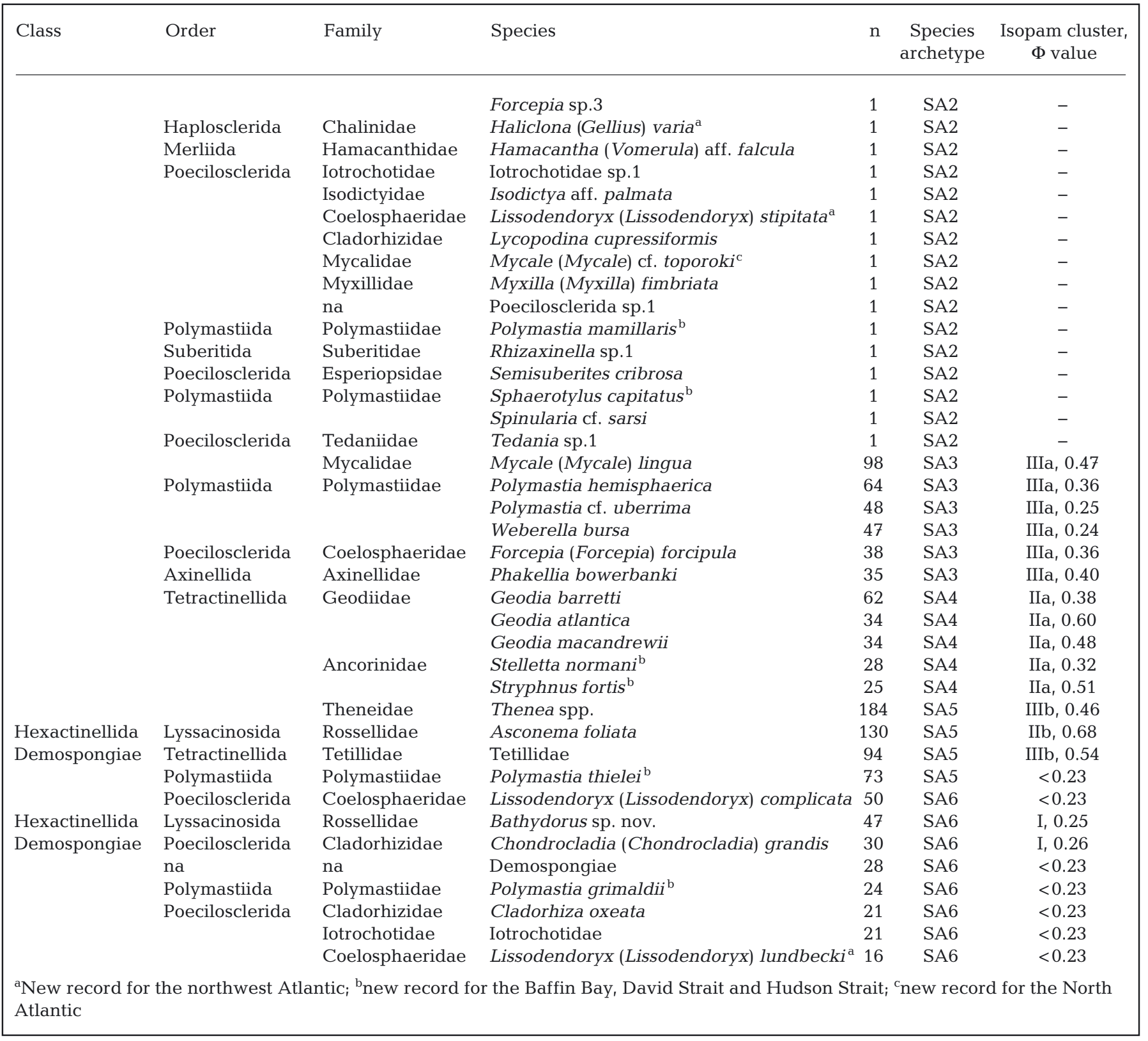

dis and Bathydorus sp. nov., but fidelity was not strong ( $\Phi=0.26$ and 0.25 , respectively). Stations assigned to this cluster group were broadly distributed throughout most of the sampled range (Fig. 4A). Cluster group II was partitioned into group IIa, a set of 5 astrophorid species (Table S1) with high fidelity to the cluster ( $\Phi$ ranging from 0.32 to 0.60 ). Only 1 species, Geodia barretti, was also significantly associated with a second cluster, IIb, although with much lower fidelity $(\Phi=0.14)$. Group IIa forms a spatially coherent group of stations (Fig. 4A) on the Canadian portion of the sill crossing Davis Strait. The second partition of this group, IIb, comprised the single species Asconema foliata, which is broadly distributed in Davis Strait (Fig. 4A). Cluster group III was also partitioned into 2 groups. Group IIIa comprised 7 species with lower fidelity ( $\Phi$ ranging from 0.24 to 0.47 ), 2 of which (Polymastia hemisphaerica and Weberella bursa) were also associated with IIb (A. foliata) albeit with lower fidelity (Table S1). Stations with this cluster group were broadly distributed throughout the sampled range (Fig. 4A). Group IIIb included a set of 

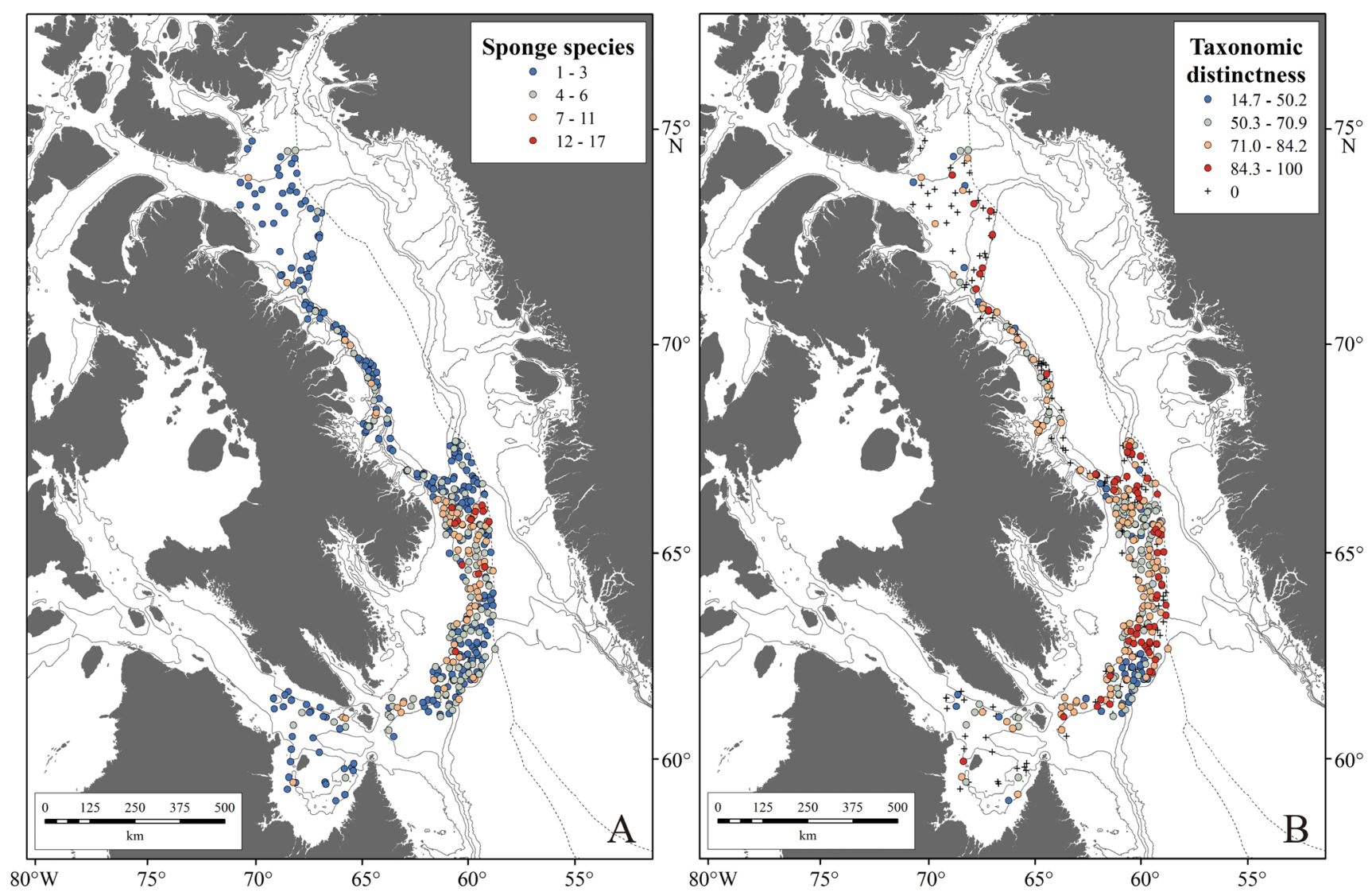

Fig. 2. (A) Number of sponge species and (B) taxonomic distinctness per station, both for the period 2010-2014

8 species (Table S1) with high fidelity to the cluster ( $\Phi$ ranging from 0.26 to 0.74 ). Three taxa, Tetillidae, Thenea spp. and Desmacella inornata, were significantly associated with group IIIa with lower fidelity ( $\Phi$ ranging from 0.20 to 0.39 ), while the astrophorid Geodia phlegraei was significantly associated with cluster IIa (the group with other astrophorids) with low fidelity $(\Phi=0.16)$. The significant association with 2 groups of Tetillidae and Thenea spp. could potentially reflect the presence of more than 1 species with different environmental requirements, although as evidenced above, this pattern is also seen for single species. Group IIIb forms a spatially coherent set of stations west of Cape Dyer, Baffin Island (Fig. 4A).

The remaining 47 species (almost half of the total number of species analysed and $67 \%$ of those present at more than 1 station) were not significantly associated with any of the 5 clusters described above, with the exception of 14 (Table S1) that were significantly associated with 1 or more cluster but had low associated fidelities ( $\Phi$ ranging from 0.14 to 0.22 ).

\section{Species archetype modelling}

Six sponge archetypes were identified in the study area. Initial models including all covariates (linear and quadratic terms) were fitted across a range of number of species archetypes $(G)$ from 1 to 15 . The first increase in $\triangle \mathrm{BIC}(G)$ occurred between 6 and 7 archetypes, indicating that the 'best' value of $G$ is 6 . Values for $\min (\pi)$ with $G=6$ showed that there were at least 4 species in every archetype, indicating that 6 archetypes likely represented the best grouping of sponges in the study area. After the stepwise variable selection, the optimal model (lowest BIC) identifying the 6 sponge archetypes included bottom temperature average maximum, spring chlorophyll a maximum, depth, summer primary production average maximum, summer primary production average range and slope. The estimated coefficients, SEs and RSEs of the components of the 6 GLMs to predict each sponge species archetypes are shown in Table S2. Species archetype composition and the membership probability of each sponge species to 

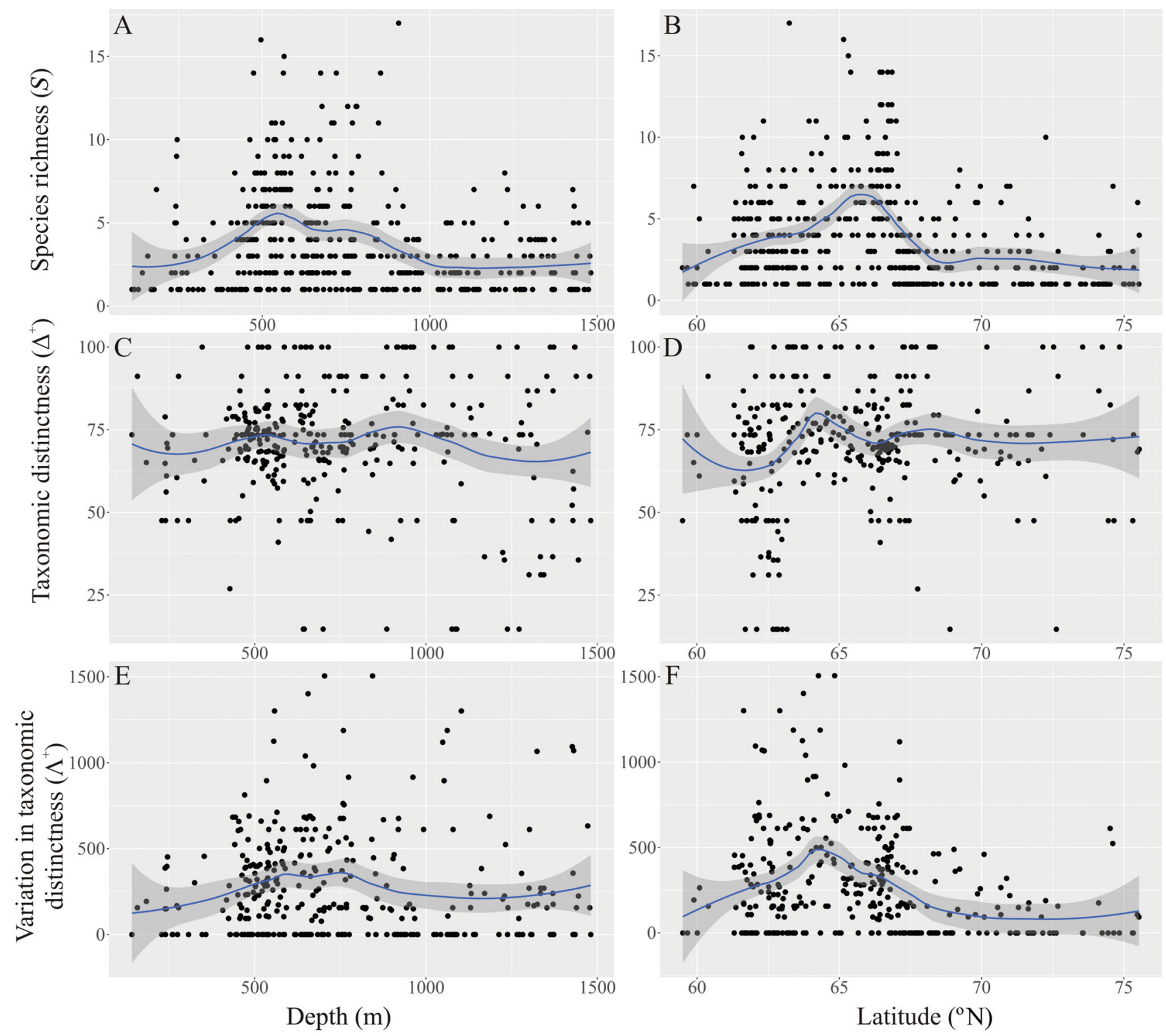

Fig. 3. Plots of $(\mathrm{A}, \mathrm{B})$ species richness $(S),(\mathrm{C}, \mathrm{D})$ taxonomic distinctness $\left(\Delta^{+}\right)$and $(\mathrm{E}, \mathrm{F})$ variation in taxonomic distinctness $\left(\Lambda^{+}\right)$

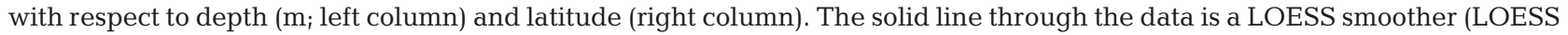
span of 0.5). The shaded area is the $95 \%$ confidence interval of the smoother

each archetype is indicated in Table S3. All species have probabilities $(\tau)$ higher than 0.95 of belonging to particular archetypes, indicating that they are strongly affiliated with the archetypes identified (Foster et al. 2015).

The 6 species archetypes (SA1-SA6) showed a coherent spatial pattern, with the exception of SA2 which had a maximum probability of 0.03 and therefore was not the dominant archetype at any sampling location (Fig. 4B). SA1 was comprised of 6 species, all with $100 \%$ probability of co-occurring (Table S3). Geodia parva, Desmacella inornata and G. phlegraei were the most frequently occurring species $(54,45$ and 43 trawl sets, respectively), but all species were well represented (range 36-54 trawl sets). SA3 included 6 species with Mycale (Mycale) lingua the most frequently occurring species (Table S3). SA4 was comprised of 5 species, all belonging to the suborder Astrophorina, with G. barretti the most frequently occurring. SA5 was comprised of 4 taxa, all very well represented (range 73-184 trawl sets), and included Thenea spp., which was the most common taxon in the study area. SA6 was comprised of 8 taxa, including 1 species group (Iotrochotidae) and Demo- 

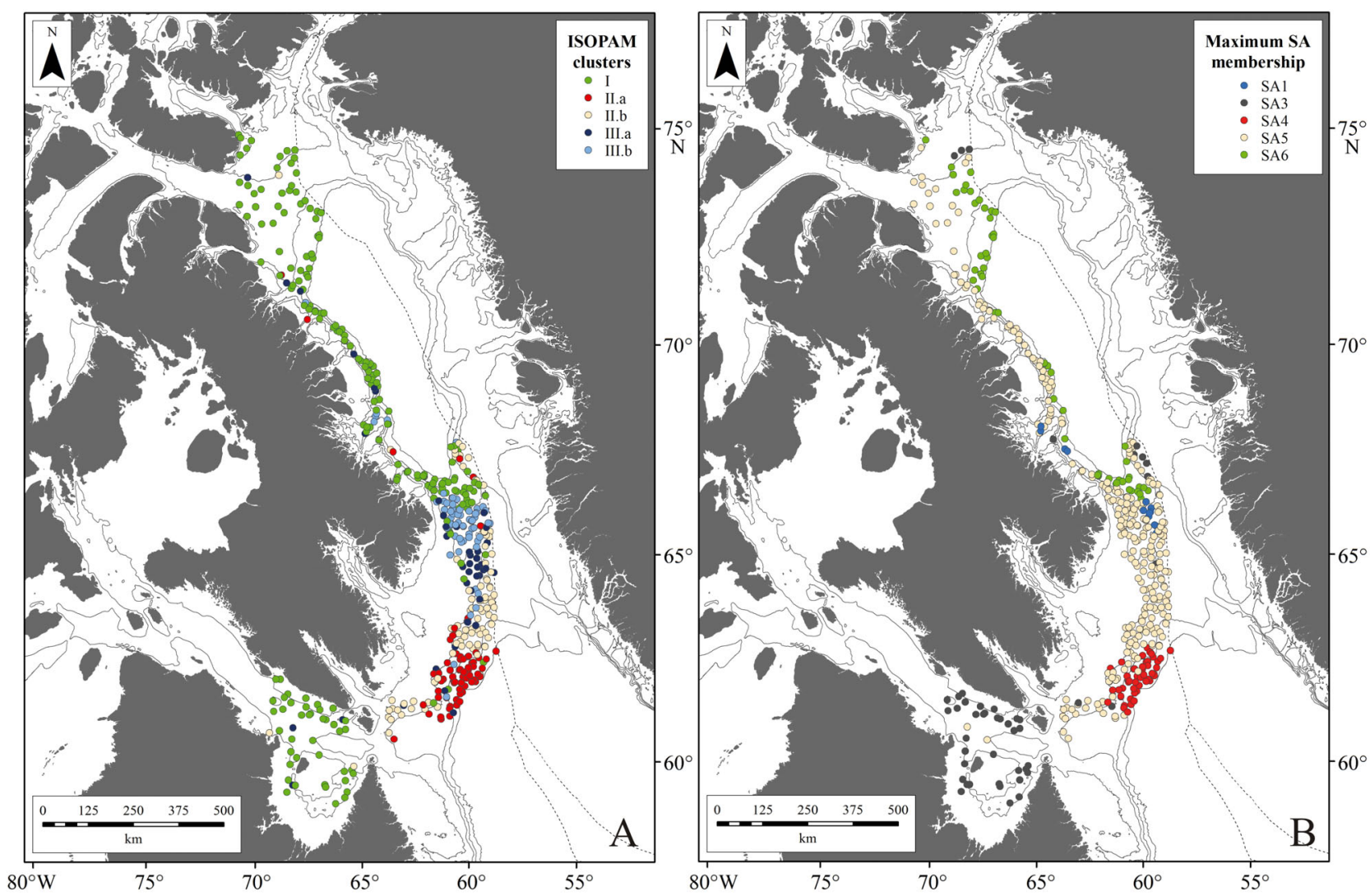

Fig. 4. (A) Spatial distribution of the Isopam-generated cluster groups. (B) Species archetype (SA) dominance in terms of probability in the sampling locations. Note that SA2 was not the dominant SA at any location and therefore is not represented in the figure

spongiae, with Lissodendoryx (Lissodendoryx) complicata the most frequently occurring (Table S3). The dominant archetype in terms of probability at each sampling station is shown in Fig. 4B. SA5 was broadly distributed, being the dominant archetype throughout the sampled range. SA1, SA3, SA4 and SA6 were spatially restricted, suggesting narrower environmental niches (Fig. 4B). The remaining archetype (SA2) contained infrequently collected species ( $\mathrm{n}=64$; Table S3) found in $<5 \%$ of trawl sets.

The species groups identified by Isopam and the species archetypes identified by SAM showed a high degree of similarity (Table 2), indicating a strong association between species groups determined by their co-occurrence and those grouped together based on their shared environmental preferences. SA1 found its equivalence with Isopam group IIIb. All species in SA1 were present with 2 additional taxa added to group IIIb, Tetillidae and Thenea spp., both also being significantly associated with group IIIa. $G$. hentscheli has the highest fidelity to the group $(\Phi=$ $0.74)$, followed by $G$. parva $(\Phi=0.65)$, with $D$. inornata having the lowest fidelity $(\Phi=0.26)$. Similarly,
G. phlegraei had the greatest fidelity to this group $(\Phi=0.42)$, but was also significantly associated with group IIa, the other group containing Geodia species. SA4 was exactly matched with group IIa, with fidelities to the group membership ranging from 0.32 (Stellata normani) to 0.60 (G. atlantica), and all species significantly associated with one another. Only G. barretti was also significantly associated with another group, namely group IIb characterized by the single species A. foliata. Both SA1 and SA4 showed a high spatial match with their associated species groups IIIb and IIa, respectively. SA3 found its equivalence with group IIIa. All species in SA3 were present with 1 additional species added to group IIIa, Iophon cf. piceum, which belonged to SA2, although present with only 0.02 probability of belonging to SA3 (Table S3). The 4 taxa in SA5 were mostly associated with groups IIIa, IIIb and IIb, the latter comprised of the single species A. foliata. SA5 included Tetillidae and Thenea spp. which, as discussed above, were significantly associated with both IIIa and IIIb, and Polymastia thielei, also significantly associated with IIIa and IIIb, although to a lesser 
degree $(\Phi=0.16$ and 0.14 , respectively). SA6 was matched by group I, which contained the 2 species C. (C.) grandis and Bathydorus sp. nov., the only significant associations of the 8 taxa in SA6. As previously mentioned, the level of association to the group for both species was low with presence in other groups but no significant association. This suggests that although these species are found in a common environment with high probability of occurrence, they are not necessarily found associated with one another. The remaining taxa were not significantly associated with any other group (Table S1) except Lissodendoryx (Lissodendoryx) lundbecki, which was slightly associated with group IIIa $(\Phi=0.17)$.

In general, the distribution of the dominant species archetypes were well aligned with the distribution of the species groups obtained from Isopam (Fig. 4A), although group I had a broader distribution than presented by their most similar archetype (SA6), and the same for IIIa with respect to SA5.

Predictions of presence probability and the SE of each sponge archetype in the study area are shown in Figs. 5 \& 6. SA1 was predicted with high probability east of Cape Dyer in Davis Strait, Hudson Strait and on the Greenlandic shelf (Fig. 5A), although these last locations were associated with a high SE (Fig. 5D), reflecting their uncertainty. Presence probability above 0.25 was found between 453 and 1394 $\mathrm{m}$ depth. This archetype response was influenced primarily by depth, bottom temperature average maximum and summer primary production average maximum and range (Table S2, Fig. 7). SA2, the group of infrequently occurring species, was predicted to occur with very low probability (maximum $=0.04$ ) in Canadian waters south of Baffin Bay and Hudson Strait and on the Greenlandic shelf (Fig. 5B,E). No single environmental variable had an important relevance in predicting this distribution (Fig. 7). SA3 had high probability of occurring in the southern part of the spatial extent from shallow waters to $1323 \mathrm{~m}$ depth (Fig. 5C,F) and was mostly influenced by bottom temperature average maximum and depth (Table S2, Fig. 7). SA4 was predicted to occur in the deepest parts of the spatial extent (Fig. $6 \mathrm{~A})$, and depth, bottom temperature average maximum and summer primary production average maximum were the most influential variables in the predictions (Table S2, Fig. 7). SA5 was predicted to occur with highest probability $(>0.25)$ along Canadian waters including Lancaster Sound, between 140 and $1661 \mathrm{~m}$ depth (Fig. 6B,E) influenced by bottom temperature average maximum. SA6 had a strong broad distribution in Canadian waters, especially north of Cape Dyer and western Hudson Strait (Fig. 6C), with probabilities above 0.1 between 319 and $1492 \mathrm{~m}$ depth and with bottom temperature average maximum and summer primary production average range having the greatest influence on the GLM.

\section{Model validation}

Most of the species presented significant correlations with their corresponding archetype (Table S3), except species belonging to SA2 where only 11 of 64 were significantly correlated. Kendall rank correlation was higher for species belonging to SA5, SA4 and SA1, in particular for Thenea spp. (0.39), Tetillidae (0.37), G. barretti (0.36) and G. hentscheli (0.34). Most of the species associated with these archetypes showed correlations above 0.2. The average AUC was higher in SA4 (0.89) followed by SA1 (0.83), SA3 (0.77) and SA5 (0.75). In SA6 and SA2, the average AUC was below 0.7 .

\section{DISCUSSION}

This study represents the first detailed description of the sponge diversity and assemblages from the eastern Canadian Arctic. Previous works (Knudby et al. 2013, Beazley et al. 2016, Kenchington et al. 2016b) have focused on documenting the distribution of sponges at a higher taxonomic level than that reported here. From an ecological perspective, our focus on a single taxocene, the sponge assemblages, is highly relevant due to the key roles that sponges play in benthic ecosystems. Our analyses have identified 5 sponge species assemblages through cooccurrence of species which correspond to 4 species archetypes with unique environmental conditions, some of which have been observed elsewhere (Klitgaard \& Tendal 2004), suggesting that these assemblages may be common to the North Atlantic and at the generic level, to the global oceans.

Two of the Baffin Bay-Davis Strait assemblages (IIa, SA4; and IIIb, SA1) identified by Isopam were defined in part by the large structure-forming $G e o-$ dia species, with G. atlantica, G. macandrewii and G. barretti typifying SA4, and G. hentscheli, G. parva and G. phlegraei typifying SA1. The Geodia species in SA4 are considered boreal fauna (Klitgaard \& Tendal 2004, Cárdenas et al. 2013b) while those in SA1 are considered to be coldwater (Klitgaard \& Tendal 2004) or arctic (Cárdenas et al. 2013b), with the ex- 

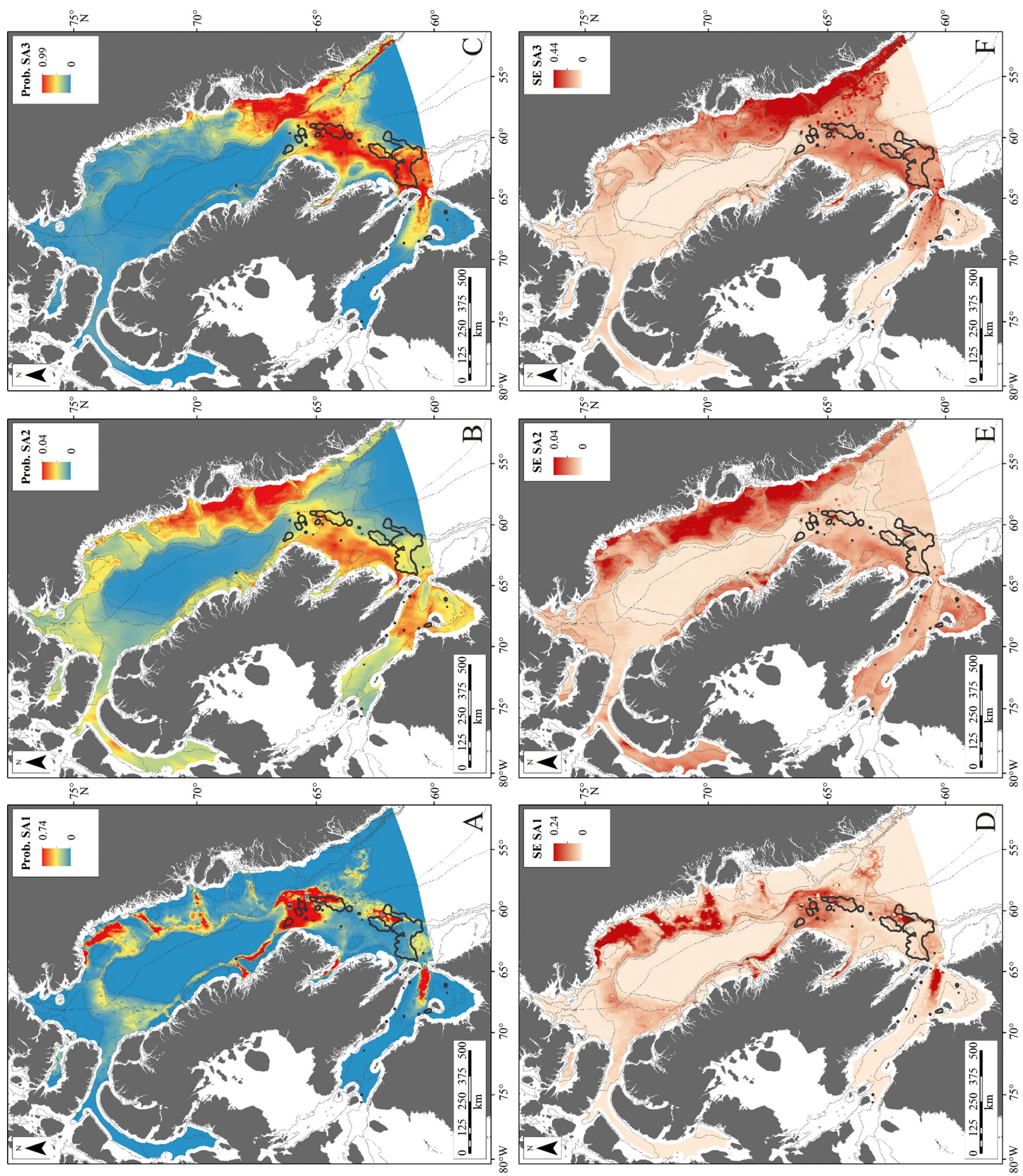

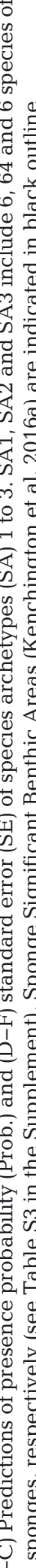



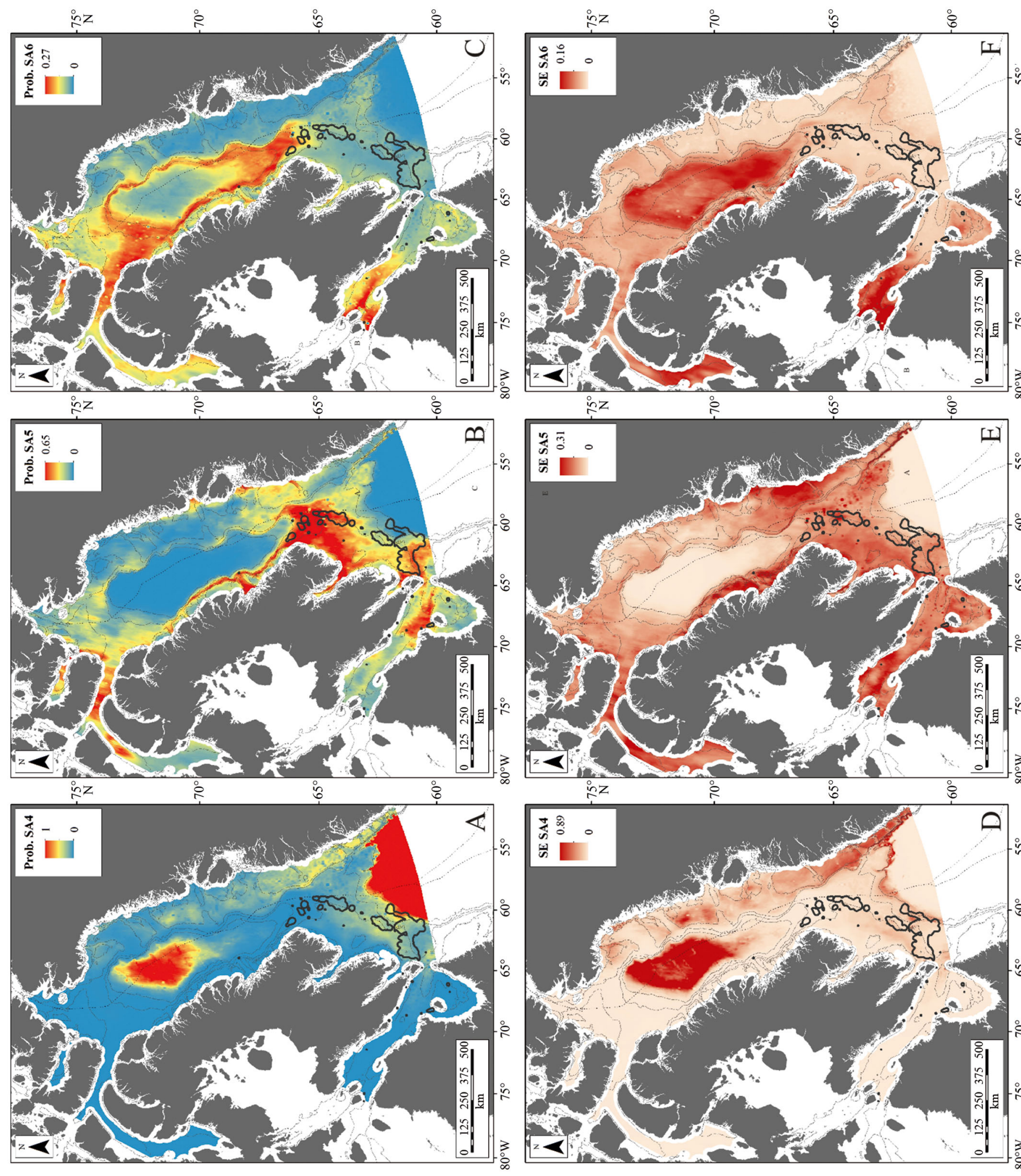

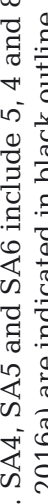

0

崖
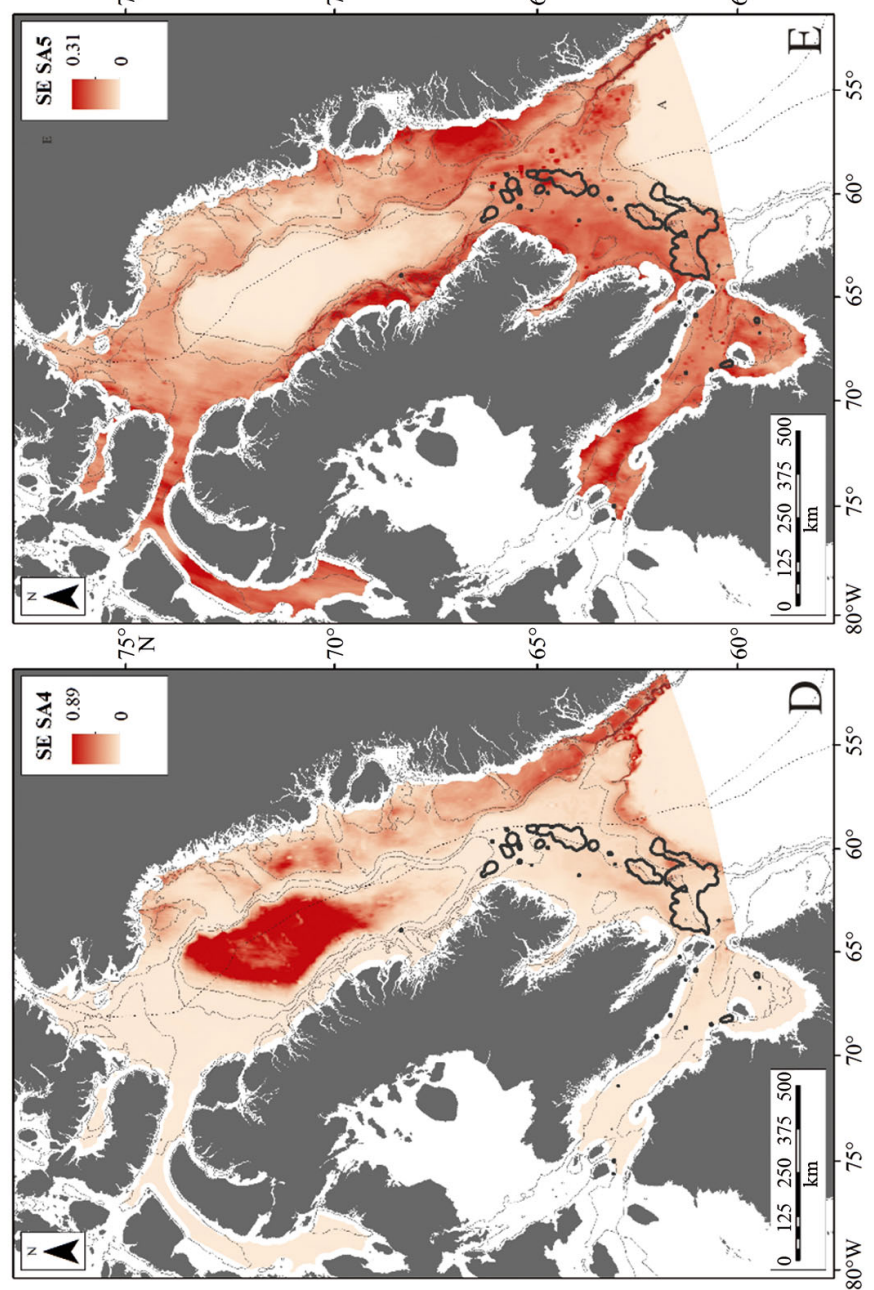

 

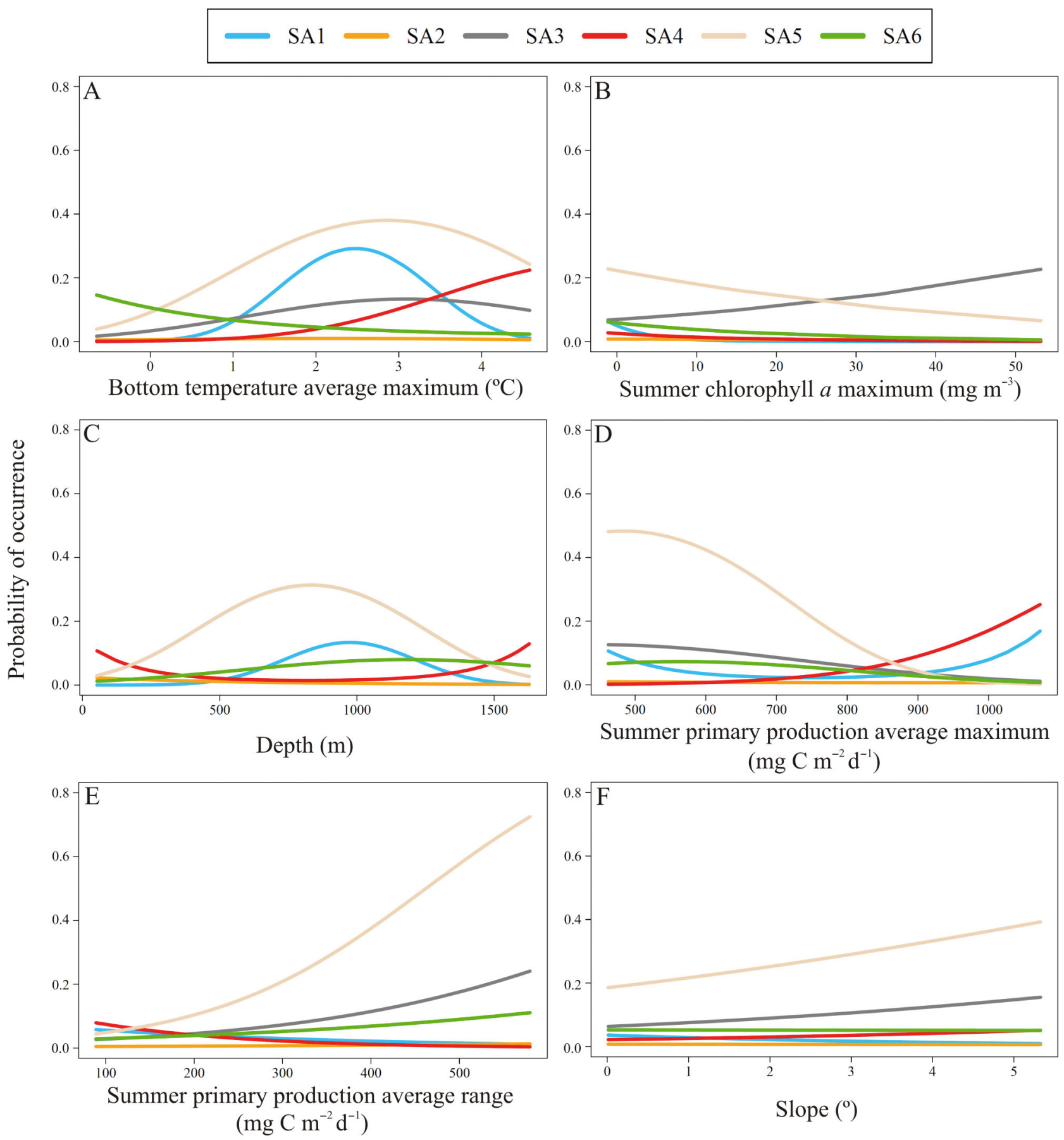

Fig. 7. Marginal probabilities of species archetypes (SA1-SA6) responses to each predictor

ception of $G$. phlegraei which is considered to be boreal (Klitgaard \& Tendal 2004, Cárdenas et al. 2013b). Although G. phlegraei was most strongly associated with the arctic Geodia species in our study, it was significantly and uniquely associated with both assemblages. Based on its known distribution, however (Cárdenas et al. 2013b, Cárdenas \& Rapp 2015), there is little doubt that this is a boreal species, although the northern records may indicate that this species is extending its range distribution. Further, Stelletta raphidiophora, another massive sponge associated with the Arctic Geodia species (SA1) has been described as an amphi-Atlantic Arctic species, while its congener $S$. normani, significantly associated with 
SA4, is boreal (Cárdenas \& Rapp 2015). Based on these indicator species, and using the biogeographic provinces proposed by Watling et al. (2013), we feel confident in describing SA1 (Table S3) as an Arctic sponge assemblage and SA4 (Table S3) as boreal. The prediction surfaces for each of these assemblages show the faunal separation by depth rather than latitude, with the arctic assemblage in the shallower waters (Fig. 4A) and the boreal assemblage in the deeper waters, specifically in Baffin Basin and the Labrador Sea (Fig. 5A).

The SA4 boreal species assemblage has also been reported on the Flemish Cap and further south in the northwest Atlantic (Murillo et al. 2012). Isopam analyses here identified an equivalent deep-sea sponge assemblage (their IIIc) at depths of 700$1400 \mathrm{~m}$ on the eastern and southeastern slopes of the Flemish Cap and on the Grand Bank (Murillo et al. 2016b). This assemblage was typified by high biomass of large, significantly associated sponges (Stryphnus fortis, G. parva/phlegraei, G. barretti, Stelletta normani) and high species richness. Analyses of spicules in sediments showed that these sponge grounds were present 130000 yr ago in at least 1 area (Murillo et al. 2016a). These massive sponges form mixed-species sponge grounds with up to 50 associated sponge species (Klitgaard \& Tendal 2004) and locally enhance biodiversity (Beazley et al. 2015). On Sackville Spur, Flemish Cap, the boreal astrophorid sponge grounds dominated by G. barretti, Stryphnus spp. and Stelletta spp. occur between 1300 and $1700 \mathrm{~m}$, coincident with the presence of a warm, saline water mass with a core beginning at $1300 \mathrm{~m}$ and extending to $1800 \mathrm{~m}$ depth (Beazley et al. 2015). This warmer and saltier layer is consistent with that of the Irminger Current. The association of ostur-type boreal sponges with the Irminger Current has been documented in the northeast Atlantic (Klitgaard \& Tendal 2004). The predicted distribution of these boreal species (SA4; Fig. 6A) below the sill of Davis Strait and in deep Baffin Bay in our study may also be, at least in part, related to the presence of Irminger Sea water. Along the west Greenland slope and shelf, the West Greenland Current (WGC) transports 2 different waters northward: cold and fresh Arctic water originating from the East Greenland Current, and warm and salty water from the Irminger Sea (Hamilton \& Wu 2013). The Irminger Sea branch of the WGC circulates westward around the Labrador Sea, where it becomes constrained by the shallow sill (maximum depth $\sim 640 \mathrm{~m}$ ) of Davis Strait (Wu et al. 2013), although a portion of this warm and salty water con- tinues north, infiltrating Baffin Bay (Hamilton \& Wu 2013). Central Baffin Bay, where SA4 was also predicted with high probability, is characterized by Baffin Bay Deep Water between 1200 and $1800 \mathrm{~m}$ depth, and Baffin Bay Bottom Water at $>1800$ m, the formation of which has not been determined (Tang et al. 2004). Note that the predictions in Baffin Bay are outside of the sampling range $(<1500 \mathrm{~m})$ and therefore not supported by observations, and the associated high SE there suggests caution should be taken; further validation is required to confirm the presence of this assemblage in the deep Baffin Bay. Additionally, the high predictions into deep zones below the sill of Davis Strait, and outside of the sampling depth range, should also be taken with caution although they are not associated with high SE. These high predictions are likely explained by the increase in probability of occurrence with depth (Fig. 7C), although this area was also predicted to have 4 or more Geodia species by Howell et al. (2016). Future validation is needed to establish the deeper limit of SA4 in this area.

The predicted distribution of the Arctic sponge assemblage SA1 (Fig. 5A) is consistent with the distribution of the cold and fresh Baffin Island Current. This archetype has a predicted distribution east of Cape Dyer in the western Davis Strait in an area where an anti-cyclonic circulation cell has been identified (Wu et al. 2012), potentially drawing down surface productivity and promoting retention there.

The co-occurrence of Chondrocladia and Bathydorus (as typified by group I, SA6) was previously observed in the deep Weddell Sea in the Southern Ocean, where cluster analysis identified a continental slope sponge community defined by Bathydorus sp. and sponges of the family Cladorhizidae at depths of 1000 to 5000 m (Göcke \& Janussen 2013). Others have noted that cladorhizids have a deep distribution facilitated by their carnivorous feeding mode (Hestetun et al. 2017). In the Baffin Bay-Davis Strait area, our model predicted a distribution in Baffin Basin and along the continental slope of western Baffin Bay, extending to Cape Dyer, Baffin Island, although the probability of occurrence was at most $58 \%$. Variables related to bottom temperature and primary production were important determinants in the model, whereas in the Weddell Sea, the community was associated with soft sediments with dropstones interspersed, the latter being important for attachment of the Bathydorus sp. Although the presence of hard substrate and sediment grain size was not considered in our analysis, Baffin Basin is known to be composed of fine silts and clays, while the lower 
slope is covered with slightly coarser fine sediments (Baker \& Friedman 1973) similar to that reported in the Weddell Sea. Dropstones are also very common in Baffin Bay (Korstgärd \& Nielsen 1989). C. (C.) grandis is a boreo-Arctic species with an amphiAtlantic distribution (Tendal \& Barthel 1993, Hestetun et al. 2017). Its branching, root-like base anchors it in soft substrates (Hestetun et al. 2017) such as those found along the continental slope and in Baffin Basin.

Phakellia-dominated sponge assemblages associated with Mycale (Mycale) lingua (group IIIa, SA3), have been reported from the Trænadypet MPA $(P$. ventilabrum) on the northern continental shelf of Norway (Kutti et al. 2013, 2015). In the northeast Atlantic, these medium-sized sponges are associated with deep, hard-bottom substrates and form a subbiotype in the marine habitat classification hierarchy (Connor et al. 2004). Polymastia hemisphaerica, P. uberrima, $M$. (M.) lingua (all species included in IIIa and SA3) and Iophon piceum (IIIa, SA2) have been reported from the top of the Flemish Cap and upper slope of Grand Bank in sandy and silty-sand bottoms with gravel presence between $130 \mathrm{~m}$ and $666 \mathrm{~m}$ (Murillo et al. 2016b). These stations formed a separate cluster from their deep-sea sponge assemblage found at the lower slope of the Flemish Cap and Grand Bank.

Although archetype SA5 only contained 4 sponge taxa (Table S3), its predicted distribution (Fig. 6B) was broad. The taxonomic difficulty in identifying species of the genus Thenea, and the fact that the family Tetillidae from the north Atlantic is currently under review (Cárdenas et al. 2013a), resulted in the coarse resolution Thenea spp. and Tetillidae taxa in SA5, and the possible inclusion of what could be multiple species with different environmental requirements. In addition, Asconema foliata is a cosmopolitan species present on both sides of the North Atlantic, Arctic and east Pacific (Van Soest et al. 2017), indicating high tolerance to different environmental conditions. Both factors can explain the dominance of these taxa and the distribution of their associated archetype (SA5) in the area.

The remaining sponge species were found across a number of cluster groups, generally with nonsignificant associations and low fidelity to the group. Many of these were associated with SA2 and had a very low distribution probability throughout. Most of these species can be considered rarities and likely have different environmental requirements, and therefore did not form well-defined associations. This group of species included most of the new records for the area and for the northwest Atlantic.
The sponge assemblages found in this study present similar distribution patterns to those from the fish assemblages identified and mapped in the area (Jørgensen et al. 2005), which in turn are driven by the different water masses and currents. This alignment of sponge and fish assemblages suggests that the sponge associations found in the area are likely related to similar responses to a common environment rather than particular interactions between the species. Astrophorids, such as the geodiids, Stelletta or Stryphnus, are massive sponges adapted to high-energy environments where they reach high densities (Knudby et al. 2013, Beazley et al. 2015) in contrast to hexactinellids or other demosponges that can have branching or tubular structures likely adapted to lower-energy regimes. The structureforming Geodia species in our study are found in areas with high primary production and fast currents that would provide high food supply needed to reach their large biomasses (up to $2 \mathrm{t}$ found in a trawl set), as seen elsewhere in the Atlantic Ocean (Klitgaard \& Tendal 2004, Fuller 2011, Murillo et al. 2012, Knudby et al. 2013).

Recently, random forest presence/absence models performed using trawl-caught sponge records identified only to the Porifera level were developed for the Eastern Arctic to aid with the identification of Significant Benthic Areas (SBAs; Kenchington et al. 2016a) and to identify important sponge areas not covered by trawl surveys (Beazley et al. 2016). It was found that in the Hudson Strait-Ungava Bay Region, the models performed poorly with an AUC of 0.643. The authors suggested that improvement in the sponge models in this region may be seen through further taxonomic breakdown of the catch records. Here, we identified 5 distinct sponge archetypes predicted to occur in the Hudson Strait-Ungava Bay Region: SA1 and SA3 around Cape Chidley, SA2 and SA 5 north of Ungava Bay and SA6 in western Hudson Strait. In particular, the sponge SBAs identified by Kenchington et al. (2016a) are dominated by different predicted archetypes: the SBAs around Cape Dyer are dominated by SA1, SA5 and SA6; the SBAs of the Davis Strait, around $65^{\circ} \mathrm{N}$, are dominated by SA1, SA3 and SA5; the 2 large SBAs eastern of Cape Chidley are dominated by SA3, SA4 and SA5; and the SBAs in Ungava Bay are dominated by SA3 and SA5. This confirms the surmise of Beazley et al. (2016) that the Hudson Strait-Ungava Bay region contains multiple sponge species with different environmental preferences. Knowledge of the distribution of these different sponge communities can be used to provide a diversity dimension to conservation planning. 
Species richness reached a maximum in Davis Strait between 450 and $900 \mathrm{~m}$ within the total depth range sampled (100 to $1500 \mathrm{~m}$ ). Strong bathymetric zonation along continental margins has long been recognized (e.g. Rex 1981, Carney et al. 1983, Carney 2005). The parabolic pattern in diversity, with peaks at intermediate (i.e. mid to lower bathyal) depths and reduced diversity at upper bathyal and abyssal depths, has been previously documented in macroand megafauna of the North Atlantic (e.g. Rex 1981, 1983, Etter \& Grassle 1992, Paterson \& Lambshead 1995, Levin et al. 2001, Rex \& Etter 2010). Lower diversity at shallower depths has been explained by elevated biotic stressors such as competitive displacement and predation (Rex 1981, 1983), while the negative, exponential relationship between food availability and depth is credited for a reduction in diversity in the abyss (Carney 2005).

The highest species richness found in Davis Strait is likely related to the fact that this area is influenced by 2 currents with different water characteristics: the cold and fresh Baffin Island Current flowing southward (Dunlap \& Tang 2006) and the warm and salty water carried by the Irminger Current offshore of Greenland (Yashayaev 2007, Wu et al. 2012), providing transitional areas for different species. The low taxonomic distinctness found in some areas of high species richness is explained by the dominance of astrophorids, rendering taxonomic distinctness low.

The 2 different methods applied in this study, one focussing solely on the co-occurrence of species in samples and the other on the common response of species to their environment, has provided a good understanding and delineation of the sponge assemblages in the eastern Canadian Arctic. Our approach is similar to the recently developed joint species distribution models (Warton et al. 2015, Ovaskainen et al. 2017) that include both co-occurrence and the environmental variables in the modelling process. However, by undertaking a separate analysis of communities using the Isopam approach, additional insight into species fidelity and constancy to the groups was provided which would otherwise not be apparent using modelling techniques alone. Further, Isopam clusters sample sites, whereas SAM clusters species; there was strong evidence that most of the species archetypes are distinct in terms of sites, which explains the good congruence between both methodologies. These results differ from those found by Leaper et al. (2014) using the SAM methodology; they did not find that communities were spatially structured in their study area due to the overlap between community types (i.e. archetype groups).
However, caution should be taken in the interpretation of archetype groups as communities because SAM groups species based on their environmental responses and therefore it tends to separate species with broader environmental tolerance ('generalist' species), such as SA5 and to a lesser extent SA3, from species with narrower environmental tolerances ('specialist' species), such as SA1 and SA4, which can overlap in the same space or community (Büchi \& Vuilleumier 2014). Consequently, these 2 methodologies may not always produce complementary results when applied elsewhere with different species compositions.

Species characterized by high fidelity to particular groups represent indicator species for the different sponge assemblages. The geodiids G. atlantica, G. barretti and G. macandrewii together with Stryphnus fortis and Stelletta normani are indicator species of the boreal sponge grounds dominated by astrophorids in the North Atlantic. G. hentscheli and Stelletta raphidiophora are indicator species of the Arctic sponge grounds, while Chondrocladia (Chondrocladia) grandis, Bathydorus sp. nov and Lissodendoryx (Lissodendoryx) complicata can be considered indicators of the Arctic slope sponge communities. Other species, such as Asconema foliata, Mycale (Mycale) lingua, the polymastiids Polymastia hemisphaerica and P. uberrima and Weberella bursa, have wider distribution ranges and are the main boreal sponge species habiting the upper slope in the northwest Atlantic. We suggest that these taxa can be used to monitor regional sponge assemblages.

Acknowledgements. This work was funded through DFO's International Governance Strategy (IGS) project 'Identification and Mapping through Predictive Modelling of Coldwater Coral and Sponge Species in the Sub-Arctic/Eastern Arctic' funded from 2015-2017 led by E.K. G.T. and F.J.M. were both funded through the NSERC Visiting Scientist in a Government Laboratory programme with source funding from IGS. We thank R. Stanley at the Bedford Institute of Oceanography and C. Goodwin from the Huntsman Marine Science Centre for their comments on earlier versions of the manuscript. We are indebted to T. Siferd from DFO, Central and Arctic Region, for assistance with the sponge collection at sea and to $\mathrm{M}$. Best for preliminary identifications. We also thank C. Yesson from the Institute of Zoology (London, UK) and 2 anonymous reviewers for helpful comments. We further acknowledge SponGES-Deep-sea Sponge Grounds Ecosystems of the North Atlantic: an integrated approach towards their preservation and sustainable exploitation. This programme was funded by H2020 - the EU Framework Programme for Research and Innovation (Grant Agreement no. 679849), and DFO is a third-party participant. SponGES scientists, Drs. P. Cárdenas, J. Xavier and others, assisted us with identifications and inspired discussion, and we consider this publication to be a contribution to SponGES. 


\section{LITERATURE CITED}

Amsler MO, McClintock JB, Amsler CD, Angus RA, Baker BJ (2009) An evaluation of sponge-associated amphipods from the Antarctic Peninsula. Antarct Sci 21:579-589

Baker RS, Friedman GM (1973) Sedimentation in an Arctic marine environment: Baffin Bay between Greenland and the Canadian Archipelago. Geol Surv Can Pap 71-23: 471-498

Baker E, Odenthal B, Tompkins G, Walkusz W, Siferd T, Kenchington E (2018) Sponges from the 2010-2014 Paamiut Multispecies Trawl Surveys, eastern Arctic and Subarctic: Class Demospongiae, Subclass Heteroscleromorpha, Order Poecilosclerida, Families Crellidae and Myxillidae. Can Tech Rep Fish Aquat Sci 3253

Beazley LI, Kenchington EL, Murillo FJ, Sacau M (2013) Deep-sea sponge grounds enhance diversity and abundance of epibenthic megafauna in the Northwest Atlantic. ICES J Mar Sci 70:1471-1490

Beazley L, Kenchington E, Yashayaev I, Murillo FJ (2015) Drivers of epibenthic megafaunal composition in the sponge grounds of the Sackville Spur, northwest Atlantic. Deep Sea Res I 98:102-114

Beazley L, Murillo FJ, Kenchington E, Guijarro J and others (2016) Species distribution modelling of corals and sponges in the eastern Arctic for use in the identification of Significant Benthic Areas. Can Tech Rep Fish Aquat Sci 3175

Beazley L, Guijarro J, Lirette C, Wang Z, Kenchington E (2018) Characteristics of environmental data layers for use in species distribution modelling in the eastern Canadian Arctic and Sub-Arctic Regions. Can Tech Rep Fish Aquat Sci 3248

Bell JJ (2008) The functional roles of marine sponges. Estuar Coast Shelf Sci 79:341-353

Bett BJ, Rice AL (1992) The influence of hexactinellid sponge (Pheronema carpenteri) spicules on the patchy distribution of macrobenthos in the Porcupine Seabight (bathyal NE Atlantic). Ophelia 36:217-226

Boé J, Hall A, Qu X (2009) September sea-ice cover in the Arctic Ocean projected to vanish by 2100 . Nat Geosci 2: 341-343

Brøndsted HV (1933) The Godthaab Expedition 1928. Porifera. Medd Gronl 79:1-25

Büchi L, Vuilleumier S (2014) Coexistence of specialist and generalist species is shaped by dispersal and environmental factors. Am Nat 183:612-624

Cárdenas P, Rapp HT (2015) Demosponges from the northern Mid-Atlantic Ridge shed more light on the diversity and biogeography of North Atlantic deep-sea sponges. J Mar Biol Assoc UK 95:1475-1516

Cárdenas P, Rapp HT, Best M, Murillo FJ, Gerasimova E, Thollesson M, Tendal OS (2013a) A revision of boreoarctic Atlantic Tetillidae (Demospongiae, Spirophorina): new records and new species. Poster presentation, 9th World Sponge Conference 2013, Fremantle, p 104

Cárdenas P, Rapp HT, Klitgaard B, Best M, Thollesson M, Tendal OS (2013b) Taxonomy, biogeography and DNA barcodes of Geodia species (Porifera, Demospongiae, Tetractinellida) in the Atlantic boreo-arctic region. Zool J Linn Soc 169:251-311

Carney RS (2005) Zonation of deep-sea biota on continental margins. Oceanogr Mar Biol Annu Rev 43:211-279

Carney RS, Haedrich RL, Rowe GT (1983) Zonation of fauna in the deep sea. In: Rowe GT (ed) The sea, ideas and observations on progress in the study of the sea, Vol 8: Deep-sea biology. Wiley-Interscience, New York, NY, p 371-398

Clarke KR, Warwick RM (2001) A further biodiversity index applicable to species lists: variation in taxonomic distinctness. Mar Ecol Prog Ser 216:265-278

Connor DW, James AH, Golding N, Howell KL, Lieberknecht LM, Northen KO, Reker JB (2004) The marine habitat classification for Britain and Ireland, Version 04.05. JNCC, Peterborough

DFO (Fisheries and Oceans Canada) (2009) Development of a framework and principles for the biogeographic classification of Canadian marine areas. Sci Advis Rep 2009/056. DFO Canadian Science Advisory Secretariat, Ottawa

Ding Q, Wallace JM, Battisti DS, Steig EJ, Gallant AJE, Kim HJ, Geng L (2014) Tropical forcing of the recent rapid Arctic warming in northeastern Canada and Greenland. Nature 509:209-212

Drinkwater KF (1988) On the mean and tidal currents in Hudson Strait. Atmos-Ocean 26:252-266

Dunlap E, Tang CL (2006) Modeling the mean circulation of Baffin Bay. Atmos-Ocean 44:99-110

*Dunstan PK, Foster SD, Darnell R (2011) Model based grouping of species across environmental gradients. Ecol Model 222:955-963

* Dunstan PK, Foster SD, Hui FKC, Warton DI (2013) Finite mixture of regression modeling for high-dimensional count and biomass data in ecology. J Agric Biol Environ Stat 18:357-375

Dunstan PK, Foster SD, Darnell R (2015) Fit mixtures of archetype species. R package 'SpeciesMix' version 0.3.4. https://cran.r-project.org/web/packages/SpeciesMix/ SpeciesMix.pdf

ESRI (Environmental Systems Research Institute) (2011) ArcGIS Desktop: Release 10. Environmental Systems Research Institute, Redlands, CA

*Etter RJ, Grassle JF (1992) Patterns of species diversity. Nature 360:576-578

Foster SD, Dunstan PK, Althaus F, Williams A (2015) The cumulative effect of trawl fishing on a multispecies fish assemblage in south-eastern Australia. J Appl Ecol 52: 129-139

Freese JL, Wing BL (2003) Juvenile red rockfish, Sebastes sp., associations with sponges in the Gulf of Alaska. Mar Fish Rev 65:38-42

Fristedt K (1887) Sponges from the Atlantic and Arctic Oceans and the Behring Sea. Vega-Expeditionens Vetenskap Iakttagelser (Nordenskiöld) 4:401-471

Fuller SD (2011) Diversity of marine sponges in the Northwest Atlantic. PhD dissertation, Dalhousie University, Halifax

Galanidi M, Kaboglu G, Bizsel KC (2016) Predicting the composition of polychaete assemblages in the Aegean coast of Turkey. Front Mar Sci 3:154

Göcke C, Janussen D (2013) Sponge assemblages of the deep Weddell Sea: ecological and zoogeographic results of ANDEEP I-III and SYSTO I expeditions. Polar Biol 36: 1059-1068

* Graham M (2003) Confronting multicollinearity in ecological multiple regression. Ecology 84:2809-2815

Grimm KJ, Mazza GL, Davoudzadeh P (2017) Model selection in finite mixture models: a k-fold cross-validation approach. Struct Equ Model 24:246-256

Hamilton JM, Wu Y (2013) Synopsis and trends in the phys- 
ical environment of Baffin Bay and Davis Strait. Can Tech Rep Hydrogr Ocean Sci 282

Herrnkind WF, Butler MJ IV, Hunt JH, Childress M (1997) Role of physical refugia: implications from a mass sponge die-off in a lobster nursery in Florida. Mar Freshw Res 48:759-769

*Hestetun JT, Tompkins-MacDonald G, Rapp HT (2017) A review of carnivorous sponges (Porifera: Cladorhizidae) from the boreal North Atlantic and Arctic. Zool J Linn Soc 181:1-61

Howell KL, Piechaud N, Downie AL, Kenny A (2016) The distribution of deep-sea sponge aggregations in the North Atlantic and implications for their effective spatial management. Deep Sea Res I 115:309-320

*Hui FKC, Warton DI, Foster SC, Dunstan PK (2013) To mix or not to mix: comparing the predictive performance of mixture models vs. separate species distribution models. Ecology 94:1913-1919

*Hui FKC, Warton DI, Foster SC (2015) Multi-species distribution modeling using penalized mixture of regressions. Ann Appl Stat 9:866-882

* Jørgensen OA, Hvingel C, Møller PR, Treble MA (2005) Identification and mapping of bottom fish assemblages in Davis Strait and southern Baffin Bay. Can J Fish Aquat Sci 62:1833-1852

Kahn AS, Yahel G, Chu JWF, Tunnicliffe V, Leys SP (2015) Benthic grazing and carbon sequestration by deep-water glass sponge reefs. Limnol Oceanogr 60:78-88

Keen CE, Keen MJ, Ross DI, Lack M (1974) Baffin Bay: small ocean basin formed by sea-floor spreading. AAPG Bull 58:1089-1108

Kenchington E, Lirette C, Cogswell A, Archambault D and others (2010) Delineating coral and sponge concentrations in the biogeographic regions of the east coast of Canada using spatial analyses. Res Doc 2010/041. DFO Canadian Science Advisory Secretariat, Ottawa

Kenchington E, Beazley L, Lirette C, Murillo FJ and others (2016a) Delineation of coral and sponge Significant Benthic Areas in eastern Canada using kernel density analyses and species distribution models. Res Doc 2016/093. DFO Canadian Science Advisory Secretariat, Ottawa

Kenchington E, Lirette C, Murillo FJ, Beazley L and others (2016b) Kernel density analyses of coral and sponge catches from research vessel survey data for use in identification of Significant Benthic Areas. Can Tech Rep Fish Aquat Sci 3167

Kenchington TJ, Kenchington ELR (2013) Biodiversity metrics for use in the ecosystem approach to oceans management. Can Tech Rep Fish Aquat Sci 3059

Kingsley MCS, Kanneworff P, Carlsson DM (2004) Buffered random sampling: a sequential inhibited spatial point process applied to sampling in a trawl survey for northern shrimp Pandalus borealis in West Greenland waters. ICES J Mar Sci 61:12-24

Klitgaard AB (1995) The fauna associated with outer shelf and upper slope sponges (Porifera, Demospongiae) at the Faroe Islands, Northeastern Atlantic. Sarsia 80:1-22

Klitgaard AB, Tendal OS (2004) Distribution and species composition of mass occurrences of large-sized sponges in the northeast Atlantic. Prog Oceanogr 61:57-98

Knudby A, Kenchington E, Murillo FJ (2013) Modeling the distribution of Geodia sponges and sponge grounds in the northwest Atlantic Ocean. PLOS ONE 8:e82306

Koltun VM (1959) Corneosiliceous sponges of the northern and Far Eastern Seas of the U.S.S.R. Translated from
Russian, 1971, by the Translation Bureau Foreign Languages Division, Department of the Secretary of State of Canada. Translation Series No. 1842. Fisheries Research Board of Canada, Arctic Biological Station, Ste. Anne de Bellevue

Koltun VM (1966) Four rayed sponges of the North and Far Eastern Seas of the U.S.S.R. (Otriad Tetraxonida). Translated from Russian, 1971, by the Translation Bureau Foreign Languages Division, Department of the Secretary of State of Canada. Translation Series No. 1785. Fisheries Research Board of Canada, Arctic Biological Station, Ste. Anne de Bellevue

Korstgärd JA, Nielsen OB (1989) Provenance of dropstones in Baffin Bay and Labrador Sea. Proc Ocean Drill Program, Sci Results 105:65-69

Kutti T, Bannister RJ, Fosså JH (2013) Community structure and ecological function of deep-water sponge grounds in the Trænadypet MPA-Northern Norwegian continental shelf. Cont Shelf Res 69:21-30

Kutti T, Fosså JH, Bergstad OA (2015) Influence of structurally complex benthic habitats on fish distribution. Mar Ecol Prog Ser 520:175-190

Lambe LM (1900) Sponges from the coasts of north-eastern Canada and Greenland. Trans R Soc Can 6:19-49

* Leaper R, Dunstan PK, Foster SD, Barret NS, Edgar GJ (2014) Do communities exist? Complex patterns of overlapping marine species distributions. Ecology 95:2016-2025

* Lesser MP, Slattery M (2013) Ecology of Caribbean sponges: Are top-down or bottom-up processes more important? PLOS ONE 8:e79799

Levin LA, Etter RJ, Rex MA, Gooday AJ and others (2001) Environmental influences on regional deep-sea species diversity. Annu Rev Ecol Syst 32:51-93

* Leys SP, Yahel G, Reidenbach MA, Tunnicliffe V, Shavit U, Reiswig HM (2011) The sponge pump: the role of current induced flow in the design of the sponge body plan. PLOS ONE 6:e27787

Kucas SG (1986) Proper syntax when using aff. and cf. in taxonomic statements. J Vertebr Paleontol 6:202

Lundbeck W (1902) Porifera. (Part I.) Homorrhaphidae and Heterorrhaphidae. The Danish Ingolf-Expedition, 6(1). Bianco Luno, Copenhagen

Maldonado M, Ribes M, Van Duyl FC (2012) Nutrient fluxes through sponges: biology, budgets, and ecological implications. Adv Mar Biol 62:113-182

Maldonado M, Aguilar R, Bannister RJ, Bell JJ and others (2017) Sponge grounds as key marine habitats: a synthetic review of types, structure, functional roles, and conservation concerns. In: Rossi S, Bramanti L, Gori A, Orejas C (eds) Marine animal forests. Springer International Publishing, Cham, p 143-183

McLachlan G, Peel D (2000) Finite mixture models. Wiley, New York, NY

Melling H, Gratton Y, Ingram G (2001) Ocean circulation within the North Water polynya of Baffin Bay. AtmosOcean 39:301-325

*Murillo FJ, Duran Munoz P, Cristobo FJ, Rios P, Gonzalez C, Kenchington E, Serrano A (2012) Deep-sea sponge grounds of the Flemish Cap, Flemish Pass and the Grand Banks of Newfoundland (Northwest Atlantic Ocean): distribution and species composition. Mar Biol Res 8:842-854

Murillo FJ, Kenchington E, Lawson JM, Li G, Piper DJW (2016a) Ancient deep-sea sponge grounds on the Flemish Cap and Grand Bank, northwest Atlantic. Mar Biol 163:63 
Murillo FJ, Serrano A, Kenchington E, Mora J (2016b) Epibenthic assemblages of the Tail of the Grand Bank and Flemish Cap (northwest Atlantic) in relation to environmental parameters and trawling intensity. Deep Sea Res I 109:99-122

Oksanen J, Blanchet FG, Friendly M, Kindt R and others (2017) Community ecology package. Ordination methods, diversity analysis and other functions for community and vegetation ecologists. $\mathrm{R}$ package 'vegan' version 2.5.2. https://cran.r-project.org/web/packages/vegan/vegan. pdf

Ovaskainen O, Tikhonov G, Norberg A, Blanchet FG and others (2017) How to make more out of community data? A conceptual framework and its implementation as models and software. Ecol Lett 20:561-576

Paterson GLJ, Lambshead PJD (1995) Bathymetric patterns of polychaete diversity in the Rockall Trough, northeast Atlantic. Deep Sea Res I 42:1199-1214

Pile AJ, Young CM (2006) The natural diet of a hexactinellid sponge: benthic-pelagic coupling in a deep-sea microbial food web. Deep Sea Res I 53:1148-1156

* Plotkin A, Gerasimova E, Rapp HT (2017) Polymastiidae (Porifera, Demospongiae) of the Nordic and Siberian Seas. J Mar Biol Assoc UK, doi:10.1017/S0025315417000285

R Core Team (2016) R: a language and environment for statistical computing. R Foundation for Statistical Computing, Vienna

Reid I, Falconer RKH (1982) A seismicity study in northern Baffin Bay. Can J Earth Sci 19:1518-1531

Rex MA (1981) Community structure in the deep-sea benthos. Annu Rev Ecol Syst 12:331-353

Rex MA (1983) Geographic patterns of species diversity in the deep-sea benthos. In: Rowe GT (ed) The sea, ideas and observations on progress in the study of the sea, Vol 8: Deep-sea biology. Wiley-Interscience, New York, NY, p 453-472

Rex MA, Etter RJ (2010) Deep-Sea biodiversity: pattern and scale. Harvard University Press, Cambridge, MA

Schmidtlein S (2015) Isopam (Clustering). R package version 0.9-13. https://cran.r-project.org/web/packages/isopam/ isopam.pdf

Schmidtlein S, Tichý L, Feilhauer H, Faude U (2010) A brute-force approach to vegetation classification. J Veg Sci 21:1162-1171

Schwarz G (1978) Estimating the dimension of a model. Ann Stat 6:461-464

Tang CCL, Ross CK, Yao T, Petrie B, DeTracey BM, Dunlap E (2004) The circulation, water masses and sea-ice of

Editorial responsibility: James McClintock, Birmingham, Alabama, USA
Baffin Bay. Prog Oceanogr 63:183-228

Tendal OS, Barthel D (1993) Chondrocladia gigantea (Demospongiae) - the giant clubsponge of the Northeast Atlantic. Deep-Sea Newsl 20:12-15

* Tichý L, Chytrý M (2006) Statistical determination of diagnostic species for site groups of unequal size. J Veg Sci 17:809-818

Tompkins G, Baker E, Anstey L, Walkusz W, Siferd T, Kenchington E (2017) Sponges from the 2010-2014 Paamiut Multispecies Trawl Surveys, eastern Arctic and Subarctic: Class Demospongiae, Subclass Heteroscleromorpha, Order Poecilosclerida, Family Coelosphaeridae, Genera Forcepia and Lissodendoryx. Can Tech Rep Fish Aquat Sci 3224

Van Soest RWM, Boury-Esnault N, Hooper JNA, Rützler K and others (2017) World Porifera database. www.marinespecies.org/porifera (accessed 6 October 2017)

Wareham Hayes VE, Fuller S, Shea E (2017) Egg deposition by Rossia palpebrosa (Cephalopoda: Rossiinae) in deepsea sponges, in temperate Northwest Atlantic and fringes of polar Canadian Arctic. Poster presentation, $10^{\text {th }}$ World Sponge Conference, Galway, p 190

*Warton DI, Blanchet FG, O'Hara RB, Ovaskainen O, Taskinen S, Walker SC, Hui FKC (2015) So many variables: joint modeling in community ecology. Trends Ecol Evol 30:766-779

* Warwick RM, Clarke KR (1995) New ‘biodiversity' measures reveal a decrease in taxonomic distinctness with increasing stress. Mar Ecol Prog Ser 129:301-305

*Watling L, Guinotte J, Clark MR, Smith CR (2013) A proposed biogeography of the deep ocean floor. Prog Oceanogr 111:91-112

*Woolley SKC, McCallum AW, Wilson R, O'Hara TD, Dunstan PK (2013) Fathom out: biogeographical subdivision across the Western Australian continental margin-a multispecies modelling approach. Divers Distrib 19: 1506-1517

*Wu Y, Tang C, Hannah C (2012) The circulation of eastern Canadian seas. Prog Oceanogr 106:28-48

Wu Y, Hannah CG, Petrie B, Pettipas R and others (2013) Ocean current and sea ice statistics for Davis Strait. Can Tech Rep Hydrogr Ocean Sci 284

Y Yashayaev I (2007) Hydrographic changes in the Labrador Sea, 1960-2005. Prog Oceanogr 73:242-276

* Zhang X, Sorteberg A, Zhang J, Gerdes R, Comiso JC (2008) Recent radical shifts of atmospheric circulations and rapid changes in Arctic climate system. Geophys Res Lett 35:L22701

Submitted: January 16, 2018; Accepted: April 3, 2018 Proofs received from author(s): May 22, 2018 